\title{
Revista do Museu Paulista e(m) capas: identidade e representação institucional em texto e imagem ${ }^{1}$
}

\begin{abstract}
Vera Lúcia Nagib Bittencourt ${ }^{2}$
RESUMO: Este artigo propõe reflexão sobre a escrita da história, a partir de estudo das capas da Revista do Museu Paulista, especialmente durante as gestões dos dois primeiros diretores da instituição, quando certa continuidade editorial foi preservada. Tomadas como "fontes", ou seja, objeto de trabalho do historiador, as capas revelam vestígios de processos que permitem reconstruir, em suas dimensões históricas, as complexas imbricações entre a produção da Revista, sua materialidade, e os atos de leitura e interpretação que condicionam e refletem relações entre produtores de textos e seus leitores nas primeiras décadas do século XX, a partir de São Paulo, onde era editada.

PALAVRAS-ChAVE: Revista do Museu Paulista. Escrita da História. Estudo de fontes. Estudo de museus. Hermann von thering. Affonso Taunay.
\end{abstract}

ABSTRACT: This paper offers a reflection about the writing of History, based on the study of Revista do Museu Paulista's covers, noticeably during the term of its two first directors, when a certain editorial continuity was preserved. Taken as "sources", namely as historian subjects, those covers reveal evidences of practices that allow one to reconstitute, in its historic dimensions, the complex connection between the creation of the Revista, its materiality, and the reading and interpretation efforts that condition and reflect liaisons with writers and readers during the first decades of the XXth Century, from São Paulo, where it was published..

KEYWORDS: Revista do Museu Paulista. Historical writing. Study of sources. Study of museums. Hermann von lhering. Affonso Taunay.

A intenção deste artigo é, a partir do estudo circunstanciado das capas da Revista do Museu Paulista, refletir sobre a escrita da história, compreendida não apenas em seu nível discursivo, mas em sentido mais amplo que intenta abranger formas particulares de inscrição do conhecimento histórico em

\begin{abstract}
1. Este artigo vincula-se a projeto de pós-doutoramento, com apoio FAPESP, $O$ Museu Paulista como lugar para a escrita da História, 1917/1945, desenvolvido no Museu Paulista/USP, que busca apreender por quais caminhos, intelectuais e historiográficos, foi reunido na Instituição expressivo acervo, tornado emblemático para uma escrita da história de São Paulo e da nação.
\end{abstract}

2. Pós-doutoranda no Museu Paulista da USP.E-mail: < vera bitten@gmail.com>. 
3. Busco apoio, especialmente em Guimarães (2008). Trata-se de referenciar estudos seminais sobre a natureza da história, com destaque para a obra de Michel de Certeau, A escrita da História, publicada em 1975, em que desenvolveu o conceito de "operação historiográfica”. As questões levantadas por Certeau foram exploradas, de forma instigante, por Paul Ricoeur (2007), especialmente no capítulo II, História/Epistemologia., item 3. A Representação historiadora, p. 247 e ss.

4. Para o processo de formação e organização do Fundo Museu Paulista, consultar Makino et al. (2003).

5. Exemplo instigante deste movimento de organização dos acervos pode ser acompanhado em relação à musealização de iconografia referente a Estevão Ribeiro de Rezende, o Marquês de Valença, em função de doações de seus descendentes. Em 1911, gestão Ihering, (Fundo Museu Paulista, p. 95), as netas do Marquês, Francisca Rezende de Almeida Mello e Lídia de Souza Rezende, doaram retratos dos avós; a partir de 1918, Lídia de Souza Rezende negociou com seu "primo",Taunay, então envolvido na preparação do Centenário da Independência, a doação de conjunto de documentos pertencentes à família, que "organizado" por Taunay, veio a constituir o Fundo Marques de Valença, no acervo do Museu. determinada cultura $^{3}$, especialmente durante as gestões dos dois primeiros diretores da instituição, quando certa continuidade editorial foi preservada. Tratase de investigar a (re)configuração de fontes, no estudo em/sobre museus, ampliando referências para a reconstituição das relações entre o Museu Paulista e seus públicos, assim como da trajetória institucional como expressão e projeção de embates sobre o passado e projetos de nação. As indagações sugeridas pelo estudo da documentação administrativa da instituição reunida no Fundo Museu Paulista ${ }^{4}$ durante pesquisa de pós-doutorado, com apoio Fapesp, voltada para a investigação do Museu Paulista como lugar para a produção de escrita da História permitiram considerar a possibilidade de recuperar a história institucional, quer seja, procedimentos e processos de formulação de projetos institucionais e suas consecuções, também por meio da publicação voltada para a divulgação da produção do Museu Paulista - Revista do Museu Paulista, destacando para análise suas capas enquanto materialidade a expressar permanências e transformações, em diálogo com leitores e parceiros. Os primeiros estudos mostraram a Revista, em que também eram publicados os relatórios dos diretores encaminhados às esferas de governo às quais o Museu esteve vinculado, marcantemente inserida nos procedimentos de organização do Museu Paulista e, assim, a determinar maior atenção nas investigações que se desenvolviam. Evidenciaram-se desdobramentos que mostraram densa conexão, inclusive no acolhimento e organização dos acervos, entre a gestão Taunay (1917/1945) e a de seu antecessor, Hermann von Ihering ${ }^{5}$ (1894-1916) e instigantes imbricações entre as práticas dos diretores e as políticas públicas, expressas em ações de governo, uma vez que o Museu Paulista formou-se e foi sediado no Monumento do lpiranga a partir de complexas negociações políticas e administrativas conduzidas pelo governo do estado, no contexto de afirmação do regime republicano, na última década do século 19.

Buscou-se, a partir do levantamento destas referências, no estudo das capas e por meio delas, apreender indícios tanto do movimento de configuração da identidade institucional enquanto projeção e reflexo de programas políiticos e culturais com que se dialogava, como compreender a função de diretor, enquanto intelectual à serviço da ciência, frente às múltiplas demandas postas pelo cargo, especialmente em suas relações tanto com esferas de governo como com frequentadores do Museu e público leitor. Trata-se de reconhecer a preocupação dos editores da Revista e diretores do Museu Paulista, Hermann von Ihering e Affonso Taunay, em ressaltar não só as intenções que traziam, mas em aproximarse de pares, valorizar conteúdo e práticas e identificar temáticas abordadas de forma a definir e fixar um espaço editorial. Especialmente para o contexto com que thering e Taunay dialogaram, a formatação de uma publicação institucional era estratégica e primordial. Por meio dela, buscava-se não só divulgar o conhecimento produzido no Museu Paulista como ter acesso, por meio de permuta com outras instituições semelhantes, à produção análoga que viria complementar e ampliar os estudos em desenvolvimento. Tratava-se de buscar "inserção", e até mesmo protagonismo, no conhecimento e classificação de fauna e flora do continente americano e em questões relacionadas com o apossamento e descrição 
do território da nação brasileira. Os diretores puderam fazer circular sua revista científica tanto no Brasil, em permutas com o Museu Nacional (RJ) e o Museu Goeldi (PA), mas também na América - com ênfase para Argentina, Chile, Estados Unidos e Canadá, e Europa. Desta forma, a preparação das capas da Revista deveria assumi-las enquanto espaço de expressão capaz de estabelecer comunicação mais imediata e assegurar prestígio. Era importante que, em interação com informações dispostas em texto, a formatação gráfica também pudesse sugerir questões e indicar tomada de posições.

Assim, ao se entender como objetivo da capa a divulgação da Revista, que composição gráfica ela deveria apresentar para potencializar e qualificar a comunicação com seus leitores? E mais: traria a capa elementos que a colocassem enquanto instrumento de combate no interior de um diálogo que se estabelecia em torno dos propósitos da instituição? Seria possível que as capas apresentassem referenciais especialmente reconhecidos por um segmento de leitores, enquanto dialogava com públicos maiores? Haveria, por meio de posições trazidas e assumidas na distinção conferida pela cuidadosa elaboração das capas, indícios de configuração de espaços de poder apoiados pela produção/domínio da ciência? De quais recursos foi possível lançar mão, frente às condições técnicas e financeiras disponibilizadas?

Reconstruir, em suas dimensões históricas, as complexas relações entre a produção da Revista, sua materialidade, e os atos de leitura e interpretação que, de certa forma, condicionam e refletem relações entre produtores de textos e seus leitores nas primeiras décadas do século XX, a partir de publicação científica editada em São Paulo, mas que se entretecia em rede ${ }^{b}$ que se desdobrava no Brasil e América do Sul, é o desafio a ser enfrentado.

Breve histórico

Em 1947, Sérgio Buarque de Holanda, então Diretor do Museu Paulista, usou o Prefácio de uma das publicações do Museu7, a Revista do Museu Paulista, para apresentar renovação do projeto editorial:

O presente volume I (Revista do Museu Paulista, N.S., vol. I) corresponde ao número 27 da série primitiva. Ressurgindo com especialização desta vez mais definida, não pareceu plausivel conservar-se, na aparência, uma continuidade que, de fato, deixava de subsistir. Entre manter-se a série primitiva da Revista e iniciar-se uma publicação inteiramente nova optou-se pela solução intermediária. Na série que se inaugura com o presente volume, a revista do Museu Paulista espera manter-se à altura das suas grandes tradições ${ }^{8}$.

Portanto, é possível identificar-se nas considerações de Buarque de Holanda algumas questões com as quais me defronto. Afirma o prefaciador: "não pareceu plausível, conservar-se, na aparência, uma continuidade" [grifo meu], ou seja, era necessário indicar ao leitor, de forma específica e concreta, novo momento da publicação e, para tanto, devia-se referenciar o processo em sua
6. Interesssantes considerações sobre a investigação da ciência como ação, na proposta da teoria ator-rede, estão em Latour (1994).

7.A partir de 1922, o Museu Paulista apresentaria duas publicações: a tradicional Revista do Museu Paulista e os Anais do Museu Paulista, lançamento de seu diretor, Affonso Taunay, logo a seguir à criação de seção de História Nacional e Etnografia, que, de acordo com as indicações presentes no Prefácio do primeiro número, destinava-se à divulgação dos trabalhos da seção e à publicação de documentos incorporados ao acervo do Museu. Os Anais do Museu Paulista foram publicados em vinte e nove tomos entre 1922 e 1987.A partir de 1993, Ulpiano Toledo Bezerra de Meneses, possivelmente inspirado em estratégia utilizada para a Revista do Museu Paulista por iniciativa de Sérgio Buarque de Holanda, lançou os Anais do Museu Paulista Nova Série, que se mantém em publicação. Ver Meneses (1993) e Makino (1980/1981).

8. Ver Holanda (1947), grifos meus. 
9. Interessante observar que entre 1938 e 1947 , o título - Revista do Museu Paulis$t a$, em função do desmembramento da seção de Zoologia do Museu, deixou de circular. Ao assumir a direção do Museu, em 1947, Sérgio Buarque de Holanda resgatou o título da publicação, enquanto propunha a ela nova linha editorial.

10. Ver Taunay (1929).

11. Sérgio Buarque de Holanda ocupou a direção do Museu Paulista de 1946 a 1956. No entanto, durante este período, em função de atividades e pesquisas na Europa, pouco esteve à frente do Museu. Herbert Baldus, durante o período, praticamente comandou a instituição. Cf.: Françozo (2005). capa. A expressão "nova série", presente junto ao título, era signo que diferenciava a publicação, em sua trajetória". Marcava, assim, o que se entendia como um novo conceito da Revista, enquanto invocava como proposta de futuro, que ela se mantivesse "à altura de suas grandes tradições".

Logo, pressupõe-se que a Revista do Museu Paulista, nos meios onde circulava, era reconhecida e gozava de credibilidade. Referenciada por Affonso Taunay, então diretor do Museu Paulista, em Prefácio ao tomo XVI publicado em 1929, como "O velho órgão do Museu Paulista, a mais antiga das publicações scientificas hoje existentes no Estado de São Paulo" 10 detinha trajetória emblemática de serviços prestados à ciência. Apresentava-se, portanto, como conveniente ao novo diretor lançar mão deste "passado" para apoiar movimento de reconfiguração no interior da própria instituição que também deveria estar indicado na publicação mais antiga do Museu Paulista. Assim, valeu-se da capa para introduzir discussão em torno das propostas que trazia e que, de alguma forma, relacionavam-se tanto com a publicação quanto com a instituição que assumia.

Sérgio Buarque de Holanda ${ }^{11}$ vinha substituir, à frente do Museu Paulista, a Affonso d'Escragnolle Taunay. Diretor da instituição de 1917 a 1945, Taunay era reconhecido e reverenciado como figura fundamental para a configuração de uma escrita da história de São Paulo que tinha na decoração do Museu sua expressão visual e em sua biblioteca e seu acervo, em grande parte frutos de sua atividade, extensa documentação iconográfica e tridimensional a referendar copiosa produção bibliográfica. Para o leitor atento, o novo momento da Revista precisava ser explicitado de forma clara e identificado de imediato, enquanto crítica ao trabalho que vinha sendo realizado e, ao mesmo tempo, indicação de necessidades renovadas aportadas por mudanças políticas, sociais e culturais, em São Paulo e no Brasil. Esta dimensão, que necessitava ser divulgada, coube também ao novo título - Revista do Museu Paulista, Nova Série - exibido na capa e explicado em Prefácio, indicar. A Revista, ainda que em outro momento - conceitual e programático, não podia desprezar como referência sua longa trajetória e, especialmente, a continuidade de publicação, capaz de avalizar, ainda que no invocar de mudanças, o projeto editorial que vinha a público. Entre seu primeiro número de 1895, até o surgimento da "Nova Série", em 1947 - momento de anunciada reconfiguração -, a Revista chegou a 23 edições para 43 anos de existência contínua, em impressionante movimento, não só de produção científica mas de atividade editorial.

Durante este longo período foram responsáveis pela preparação e edição da Revista os diretores do Museu Paulista - Hermann von thering (1895/1916) e Affonso d'Escragnolle Taunay (1917/1945).

Vale ressaltar que a substituição do primeiro diretor do Museu Paulista e, consequentemente, primeiro editor da Revista, em 1916, não significou a interrupção do projeto editorial. Ainda que em novo contexto, consequência inerente à troca de diretores/editores, a Revista do Museu Paulista foi retomada, mantida e muito bem cuidada, enquanto importante órgão de divulgação científica, durante toda a gestão Taunay, ou seja, de 1917 até 1945. Assim, de maneira 
visceral, imbricavam-se as trajetórias da instituição e de sua Revista, percorrendo e expressando período longo e denso da história de São Paulo e do Brasil.

primeiro número de A Revista do Museu Paulista, datado de 1895 e publicado em 1897, concretizou proposta que vinha se configurando desde as gestões iniciais em torno da formação de um museu do estado, em São Paulo. Em 1894, Cesário Motta Junior, Secretário de Estado dos Negócios do Interior no governo de Bernardino de Campos ${ }^{12}$ (1892/1896), aprovou e mandou publicar o Regulamento do Museu Paulista, autorizado pela lei n. 200, de 29 de agosto de 1893, para funcionar no Monumento erguido no Ipiranga. Em meio a contexto político altamente conturbado pela Revolução Federalista (1893/ 1895) e frente a enormes desafios propostos para o desenvolvimento do Estado, buscavase intensificar, em meio a processos de (re)construção da nação, a afirmação do regime republicano. Urgia atender às expectativas de afirmação nacional, tanto no plano econômico, ou seja, o desenvolvimento da cafeicultura - mão-de-obra, transportes, financiamento de safras - quanto para o social e cultural, com a formação do cidadão. Tal contexto reproduzia-se e, até mesmo intensificava-se, no estado de São Paulo, então centro do desenvolvimento cafeeiro e em intensa disputa política pelo controle do governo do país. Em grande atividade, e frente às lutas políticas, o Partido Republicano Paulista buscava consolidar seu poder no âmbito estadual, sem deixar de considerar as resistências, frente a propostas políticas, de lideranças muito envolvidas com ideais positivistas no seio da agremiação. Era condição, para os que pretendiam conduzir o Partido, acomodar dissidências e, quando as negociações revelavam-se infrutíferas, partir para o confronto $^{13}$. Portanto, ao se inserir iniciativas como a formação do Museu Paulista no quadro político e social paulista, se pode perceber a complexa composição em torno de concepções díspares, especialmente no acompanhar as instâncias administrativas - no caso, a formação do museu no âmbito da Secretaria dos Negócios do Interior - onde o projeto de um museu para o estado se definia.

Desta forma, torna-se esclarecedor e imprescindível uma análise dos instrumentos de organização de que lançava mão a administração pública, em suas ações de governo. Previa o regulamento aprovado para o Museu Paulista:

Art. $1^{\circ}$. O Museu Paulista tem por fim estudar a historia natural da America do Sul e em particular do Brazil, cujas producções naturaes deverá colligir, classificando-as pelos methodos mais acceitos nos museus scientificos modernos e conservando-as, acompanhadas de indicações, quanto possível, explicativos, ao alcance dos entendidos e do publico. (..)

Art. $2^{\circ}$. $\bigcirc$ caracter do museu em geral será o de um museu sul-americano, destinado ao estudo do reino animal, de sua historia zoológica e da historia natural e cultural do homem. Serve o Museu de meio de instrução publica e também de instrumento scientifico para o estudo da natureza do Brazil e do Estado de S. Paulo, em particular.

Art. $3^{\circ}$. Alem das collecções de sciecias naturaes: zoologia, botânica,
12. A atuação de Bernardino de Campos para a definição dos rumos da instituição que se pretendia desenvolver em São Paulo foi marcante. Por ocasião da morte do político, Hermann von Ihering, registrou em Relatório do ano de 1915 , publicado posteriormente porTaunay, o seguinte: Muito sentido foi nesta repartição o fallecimento do illustre estadista, senador dr. Bernardino de Campos, protector desta repartição, que fundou, quando pela primeira vez presidente do Estado", cf. Ihering (1918). Em notas biográficas sobre a família Dora von Ihering Bonança (1984) citou importante papel desempenhado pelo então presidente do estado de São Paulo na indicação do nome do avô para a direção do Museu Paulista; ver: Bonança.

13. Para entender estes movimentos, ver Casalecchi (1987), Janotti (1986), Love (1982) e Queiroz (1986). 
14. Cf. Regulamento do Museu Paulista do Estado de São Paulo (1984).

15. Nascido em 1850 , em Kiel (atual Alemanha), doutor em medicina (1873) pela Universidade de Göttingen e pós-doutorado em zoologia, em 1876. Veio para o Brasil em 1880; estabeleceu-se no Rio Grande do Sul.Três anos após sua chegada, foi contratado como naturalista-viajante pelo Museu Imperial e Nacional, quando dirigia a instituição Ladislau Netto que contratou vários cientistas estrangeiros para o $\mathrm{Mu}$ seu, como, além do próprio Hermann Von Ihering, Fritz Müller, Emílio Goeldi, Wilhelm Schwake. Nesta função permaneceu até 1891.A mudança do regime, com a proclamação da República, trouxe novas políticas para o Museu Nacional, quando pesquisadores foram desligados da instituição. Desempregado, buscou ajuda entre amigos e, por sugestão de Albert Löefgren, botânico, então atuando na Comissão Geológica e Geográfica de São Paulo sob direção de Orville A. Derby, foi indicado para dirigir a seção de zoologia da Comissão. No entanto, suas expectativas eram por assumir a direção de um museu voltado para História Natural. Decisão do governo do estado de São Paulo, que optou por ocupar o Monumento do Ipiranga com um museu, veio ao encontro destas expectativas e Ihering conseguiu assumir a direção do museu do estado (1893), nomeado Museu Paulista, aberto ao público em $07 \mathrm{de}$ setembro de 1895 . Sobre a trajetória de Ihering ver Lopes (2005) e Alves (2001).

16. Relatório de 1894 , Cesario Motta, apud: Moacyr (1942), grifos meus.

17. Encaminha debate sobre a relação "construída" entre natureza, território e soberania, o estudo de Andermann (2007). mineralogia, etc. - haverá no Museu uma secção destinada a Historia Nacional e especialmente dedicada a collecionar e archivar documentos relativos ao período de nossa independência política.

Parag. $1^{\circ}$. Nas galerias e lugares apropriados do edifício serão collocadas as estatuas, bustos ou retratos a óleo de cidadãos brazileiros que, em qualquer ramo, de actividade tenham prestado incontestáveis serviços à Patria e mereçam do estado a consagração de suas obras ou feitos e a perpetuação de sua memória.

\section{(...)}

Parag. $4^{\circ}$. No mesmo Museu haverá logar para o quadro de Pedro Americo, commemorativo da Independencia e para outros de assumpto de historia e costumes pátrios, adquiridos ou offerecidos ao Estado.

Parag. $5^{\circ}$. Haverá também no Museu uma collecção numismática ${ }^{14}$.

A leitura do Regulamento remete à proposta para a instituição bem delineada e detalhada, ainda que acomodando diferentes visões e expectativas. Muito provavelmente, Hermann von Ihering ${ }^{15}$, que viria a ser nomeado diretor do Museu, participou do projeto indicando, de acordo com suas concepções e formação, algumas das áreas de atuação do Museu do Estado. No entanto, a intenção de lhering em desenvolver, em São Paulo, um museu dedicado à pesquisa científica, nos moldes dos museus europeus e norte-americanos de História Natural, precisou dialogar e compor com outras forças que atuavam no cenário político e delineavam ações de governo no estado. No relatório que encaminhou à Presidência da Província, ainda em 1894, o secretário Cesário Motta cuidou de enfatizar as instruções que haviam sido passadas ao diretor nomeado, onde a pluralidade de objetivos era acentuada, mas revelando uma proposta de construção de memória capaz de ação inspiradora:

(...) Reunir telas que perpetuem feitos de nossos antepassados, seus hábitos e costumes; que retratem a sua natureza, a beleza da zona que habitamos, a sua riqueza em todos os reinos é, além de um documento para a história de nossa civilização, um meio de se dar educação estética à população, de se protegerem vocações notáveis, de se dar impulso a todas as esferas de atividade, cujo movimento harmonioso constitui o progresso de um povol... $)^{16}$.

Passado e futuro se imbricavam.

Neste cenário, portanto, é importante reconhecer que a configuração de um museu de história natural não excluía projeto político e social para a nação, ainda que se reservasse "à ciência" espaço fundamental na afirmação do controle sobre a natureza e território ${ }^{17}$. Sediar um museu no Monumento do lpiranga ${ }^{18}$, da mesma forma, implicava em dialogar com a memória da Independência e do regime monárquico, em tempos de República. Como o mencionado relatório também indicava, o acervo de pinturas em poder do governo proveniente de 
compras realizadas durante o período monárquico e continuadas após a passagem para a República deveria ser colocado em exposição, de modo a configurar narrativa sobre o passado que contribuísse para conferir identidade. Sem desconsiderar que lideranças políticas do estado defendiam o "uso público" do espaço, isto é, que ali fossem alocadas iniciativas voltadas para a formação do cidadão. Ou seja, a abertura do museu refletiu diferentes ideais e, até mesmo, posições conflitantes ${ }^{19}$. A partir do Regulamento e do Relatório, acima parcialmente transcritos, é possível identificar suas múltiplas destinações: Museu de História Natural sul-americano a serviço da "instrução pública"20, que deveria abrigar uma seção de história nacional dedicada "a colecionar e arquivar documentos relativos ao período da nossa independência política". A condição de panteão, também antevista, concretizava-se no projeto decorativo e na ênfase sobre a pintura de Pedro Américo, a ocupar espaço privilegiado, na instituição.

Para abrigar o museu, a partir da perspectiva institucional defendida por Ihering, foram necessárias inúmeras medidas de adequação dos espaços no interior do Monumento. $\bigcirc$ diretor da instituição entendia que era fundamental para o serviço à ciência da natureza, ao qual o Museu Paulista deveria se devotar, vinculação à pesquisa de campo realizada por viajantes/cientistas. A partir do trabalho de coleta a ser assim realizado, o espaço museal cuidaria, então, de sediar estudos voltados para a identificação e catalogação de espécimes ${ }^{21}$. Pelas páginas da Revista, Ihering defendeu o que identificava como "modelo europeu" de museu, com espaço para diversos laboratórios e áreas expositivas. Era uma decisão especialmente do diretor o que exibir e como, a partir das viagens que organizava e do material que recebia. $\bigcirc$ devotamento à classificação e taxidermia determinava que as áreas de visitação fossem, inclusive, proporcionalmente menor do que a dos laboratórios. A Revista, meio pelo qual os trabalhos desenvolvidos pela equipe a serviço do Museu e por seu diretor chegariam ao público, era fundamental, na medida em que contribuía para legitimar iniciativas e alimentar proposta que via na ciência esteio para a tomada de diferentes decisões, inclusive de governo.

Está bem definido o plano pela lei que organisou o Museu, destinando-o a esclarecer a fauna, o reino mineral, o homem do Brazil e sua historia. Estão separadas as colecções expostas das de estudo, sendo o andar térreo destinado a estas e á administração, laboratórios, bibliotheca, etc., e o primeiro andar ás collecções expostas. Do trabalho scientifico é esta Revista que há de dar conta, e espero que o presente volume [volume II] poderá ser considerado neste sentido como útil, contribuindo para collegir materiaes dos quaes mais tarde será possível organisar um quadro exacto e completo do reino animal do Estado ${ }^{22}$.

Pelas iniciativas do primeiro diretor, entende-se que eram seus interlocutores grupos de cientistas ligados às teorias evolucionistas ${ }^{23}$, estabelecidos nas Américas e também na Europa, que buscavam comprovação de seus pressupostos teóricos. Assim, a Revista do Museu Paulista buscou, por meio de permutas com importantes bibliotecas, norte-americanas e européias, fazer-se
18. Declarado concluído em 1890, a destinação do monumento foi surpreendida pela mudança do regime, com a Proclamação da República, em 1891. Em 25 de agosto de 1892, o Congresso do Estado, pela lei n. 76, declarou o Monumento e suas dependências próprio do estado; em 1893 , foi votada lei que destinava o Monumento para Museu do Estado.

19. O próprio Ihering sentiu necessidade de relatar as complexas gestões que o levaram a assumir o posto, reproduzindo, no primeiro número da Revista, carta de Orville A. Derby, chefe da Commissão Geographica e Geologica de S. Paulo, que dava conta de momentos do processo. Cf.: Ihering (1895). Interessante observar que, na carta, refletindo o "contexto republicano" que se buscava desenvolver, Derby dirige-se a Ihering, como: "cidadão", atestando questões referentes à configuração da cidadania na república. Este tratamento oficial permanece nas correspondências do diretor, reunidas no Fundo Museu Paulista, enquanto forma de tratamento preponderante até meados de maio de 1898 . Mais uma vez, refletiam-se na correspondência movimentos políticos; a eleição de Campos Salles e sua posse na presidência da república do Brasil (1898) remetia à crise da presença dos republicanos radicais, os "jacobinos", tanto em dimensão nacional como estadual. Ver Queiroz (1986) e Carvalho (1990).

20. Maria Stella M. Bresciani, em sua tese de doutoramento, propõe análise instigante sobre as mediações renovadas propostas pela implantação da República, no Brasil, especialmente no instituir-se do "povo-nação", em sua relação com a instrução pública.As propostas de formação de um Museu do Estado, em São Paulo, refletem estes debates e sugerem a ampliação do processo de "civilização para o progresso", que, origi- 
nando-se na ação da escola, deveria expandir seus meios e incluir, a partir dos grupos em idade escolar, segmentos mais abrangentes da população, inclusive o contingente imigrante que deveria se integrar à nação e desenvolver sentimentos de identidade e pertencimento.O passado monárquico, por exemplo, não estava distante do entendimento de uma "evolução política" da monarquia para a república entre os italianos, que chegavam para constituir a mão-de-obra, na cidade de São Paulo.Ver Bresciani (1976).

21. A necessidade de referendar procedimentos pode ser acompanhada em diferentes momentos da Revista. Já em seu segundo número, Ihering considerou importante expor e defender suas concepções para o museu, por meio da Revista, sustentando-as em projetos que se desenvolviam na Europa e também na América do Sul.Ver Ihering (1897)

22. Ver Ihering (1897, p. 7), grifo meu.

23. Em estudo que enfoca o Museu Paulista, estas condições são aprofundadas por Gualtieri (2008), especialmente capítulo 2 (A exploração científica do Estado no Museu Paulista e os referenciais neolamarckistas), p. 90 e ss.

24. Observação de Dora von Ihering Bonança (1984, p. 164), em recomposição da trajetória familiar; grifo no original.

25. A Europeana foi lançada em 2008 com o objetivo de tornar o patrimônio cultural e científico da Europa acessível ao público. Permite às pessoas explorar os recursos digitais de museus, bibliotecas, arquivos e colecções audiovisuais da Europa. Promove oportunidades de descoberta e de atividade num espaço multilingue onde os utilizadores podem colaborar, partilhando e sendo inspirados pela rica diversidade presente em contexto de investigações que interligava diferentes cientistas de diferentes países.

O Museu prosperava grandemente na ciência, inclusive publicando uma revista tida como obra superior (Revista do Museu Paulista) nos meios científicos, seu Diretor e o filho se alteando também no conceito de cientistas da Europa, onde fixavam seus nomes pelas excelentes publicações ${ }^{24}$.

Como possível resultado deste esforço, podemos encontrar atualmente, no projeto europeana ${ }^{25}$, os doze primeiros números da Revista digitalizados e disponíveis para acesso, provenientes da Biodiversity Heritage Library, atestando esforço, já em momento da publicação dos diferentes números, de inserção em contextos mais amplos. No inquérito administrativo que resultou na demissão de Ihering, em 1916, questão apontada foi o "desaparecimento" de exemplares de revistas da Biblioteca do Museu Paulista, obtidos por permuta com centros de pesquisa europeus e norte-americanos, que teriam sido apropriados por thering 26 , a reforçar os indícios de ampla circulação do periódico. Por outro lado, cumpre conjeturar sobre os motivos que determinam que somente possam ser encontrados disponíveis no site da europeana os 12 primeiros volumes da Revista. Ao assumir a direção da instituição, Affonso Taunay buscou manter os contatos estabelecidos anteriormente, muitas vezes com muita dificuldade. Instigantemente, apenas os três primeiros números sob sua direção aparecem em bibliotecas européias parceiras do projeto europeana, a sugerir que as relações construídas por thering não puderam ser mantidas. Talvez isto indique a atuação de uma geração de homens de ciência que criaram redes de sociabilidade ${ }^{27}$ e já não mais estavam partilhando projetos por meio de publicações; por outro lado, pode também significar que uma nova linha editorial estivesse encontrando dificuldades para manter antigos parceiros, ainda que optasse por se afirmar em dedicação a questões mais vinculadas a contexto local ou nacional. Da mesma maneira, também se pode conjeturar sobre mudanças de cunho político e social com as quais dialoga a comemoração do centenário da Independência, no Brasil, em contexto de acirrados debates em torno da identidade nacional.

Outra dimensão, relacionada à produção e circulação da Revista também precisa ser considerada. Interessante lembrar que a vinculação entre pesquisa e economia já vinha se desenvolvendo e era cada vez mais importante para grupos ligados à produção cafeeira e que mantinham e ampliavam presença em postos de direção, em São Paulo e no Brasil ${ }^{28}$. Estas intenções também deveriam encontrar espaço na Revista que, no movimento de sua concepção, teve esta pluralidade de alguma forma preservada.

Cap.III: Da administração

Art. 39. $\bigcirc$ "Museu Paulista" publicará, sob a redacção do director, uma "Revista" na qual serão publicadas as investigações realizadas sobre as 
especialidades da repartição, contribuições para o conhecimento do Brazil e relatórios sobre todas as publicações que se referem a sua historia natural.

Parag. $1^{\circ}$. Na mesma "Revista" se publicarão os relatórios de viagens e estudos feitos pelos empregados que o diretor julgar útil divulgar.

Parag. 20. Também serão feitas nesta "Revista" as publicações de sábios especialistas que houverem effectuado estudos com o material do Museu.

Parag. $3^{\circ}$. Estas publicações poderão ser feitas em francez, inglez ou allemão, mas sempre acompanhadas de um extrato em lingua portugueza ou da respectiva traducção.

Parág. 4. A "revista" terá uma edição de 1.000 exemplares dos quaes 300 se destinam a permutas com periódicos de sociedades sabias, 200 à disposição do Secretario do Interior e os restantes ficam no estabelecimento para distribuição ou venda, a critério do director.

Art. 42. As investigações realizadas (...) poderão ser publicadas em periódicos extrangeiros, mediante o prévio consentimento do Secretario do Interior. ${ }^{29}$

Assim, uma "revista" se apresentava fundamental para divulgar estudos e estabelecer relações entre pares - cientistas e instituições, dando continuidade, por exemplo, a iniciativas anteriores, como as desenvolvidas pela Comissão Geográfica e Geológica de São Paulo (1886/1931) de mapeamento de território ou identificação de áreas com solo adequado às atividades agrícolas. Organizada por Orville Adelbert Derby, a Comissão Geográfica e Geológica tinha entre seus objetivos atender, por meio de atividades de exploração e análise de estudos de campo, aos crescentes desafios postos ao desenvolvimento da cultura cafeeira, em São Paulo. ${ }^{30}$ Sua atuação, como já mencionado, esteve no movimento de formação do Museu Paulista:

(...) muitas entidades científicas e técnicas oficiais, até hoje em plena atividade no Estado, originaram-se de desdobramentos da CGG, como foi o caso dos Institutos Agronômico e Geofísico, Geográfico e Cartográfico, Geológico, Florestal, e de Botânica; dos Museus Paulista e de Zoologia; e do Serviço de Hidrografia, atualmente localizado no Departamento Estadual de Águas e Energia Elétrica ${ }^{31}$.

Cabe cogitar sobre possíveis interesses, inclusive políticos, nestes estudos científicos, uma vez que o secretário do interior reservava para si duzentos, dos mil exemplares a serem impressos. Já para a primeira gestão do Museu Paulista, ou seja, os "anos Ihering", ficava evidente que o governo entendia ser parte e beneficiário do esforço de pesquisa, quanto ao "conhecimento do Brasil", orientado pela instituição. Deveriam ampliar os escopos de investigação estudos de pragas agrícolas e seu controle, de forma a garantir a expansão da produtividade, mais o mapeamento de doenças que afetavam a mão-de-obra e se propagavam pelo estado, sustentando ações de governo. A contrapartida para a pesquisa científica, desenvolvida com recursos públicos, seria a publicação de seus resultados e procedimentos. Vale, portanto, destacar que ao Museu então do patrimônio cultural e científico da Europa. [www. europeana.eu/portal], acessado em maio de 2011

26. Repetidas vezes, a documentação do Fundo Museu Paulista remete a esta situação, uma vez que Afonso Taunay procurou enfatizar não só as lacunas nas coleções da biblioteca como em documentar seus esforços em retomar as permutas com outras instituições. No entanto, memórias da neta de Ihering relatam: Veio a Grande Guerra de 1914.A inveja e a cobiça fizeram a tristeza desabar sobre nós! Sem entender, assisti à cena que deu o fio da meada das calúnias e injustiças que perseguiram meu avô. Brincávamos no jardim junto ao museu quando mamãe viu, saindo da porta do fundo, um garoto carregando pesa da cesta com livros e foi verificar do que se tratava. Vendiam esse material precioso para incriminar o Diretor! - foi o começo. Cf. Azevedo (2000)

27. O conceito de "redes" para as relações entre intelectuais vem se desenvolvendo, por meio de vários estudos que colocam em debate, por exemplo, a noção de campo intelectual que procede da sociologia cultural de Pierre Bourdieu, para expandi-lo para além da dimensão nacional. Especialmente para o cenário latino-americano, em que Ihering atuava, é enriquecedor o acompanhamento do projeto "História dos intelectuais na América Latina", dirigido por Carlos Altamirano (2010).

28. Estudos deTamás Szmrecsányi procuraram mapear a gênese e desenvolvimento das instituições de pesquisa do Estado de São Paulo durante a primeira República, muito vinculadas às demandas postas pelo desenvolvimento da agricultura e, em especial, da cafeicultura.Ver, em especial, Szmrecsányi (1996). 
29. Regulamento do Museu Paulista do Estado de São Paulo (1894).

30. Ver Figuerôa (1987).

31. Ver Figuerôa (1996, p. 169 , nota 226), grifo meu.

32. Conforme considerações de Sirinelli (1996) e retomadas, para o período que estudo para o caso brasileiro, por Gomes (2010, p. 11-30). organizado cabiam pesquisa e difusão de conhecimentos: a atividade de naturalistas viajantes aportava material aos laboratórios do Museu e, com o auxílio de cientistas, se deveria refletir sobre ele para, imediatamente, cuidar da divulgação dos conhecimentos ou de colocar para debate teorias e descobertas, por meio da Revista. A publicação cumpria papel de incentivar e pautar propostas em torno de diferentes questões.

Demandas externas, portanto, também se refletiriam na intenção de tornar público os estudos realizados no Museu; mas, também sugerem que este trabalho de pesquisa deveria se alinhar com múltiplos interesses, ou seja, cooperar com ações de governo e iniciativas voltadas para a produção agrícola e a ocupação do território. Ainda carecem de maiores estudos os embates em torno da relação estado-território-governo no início do século XX no Brasil, enfatizados com a implantação da República, especialmente em seu diálogo com instituições culturais, ao contrapor teorias e ideais políticos.

Está na "capa": a Revista do Museu Paulista e sua trajetória

Em 1895, quando o diretor do Museu Paulista, Hermann von thering, reuniu uma série de artigos para publicação, São Paulo vivia expressivo crescimento. A cafeicultura, em expansão, ocupava terras, demandava mão-deobra, exigia modernização dos transportes e desenvolvimento de sistema financeiro e bancário. No entanto, comércio e indústria também se sofisticavam; em constante expansão, atraíam população para as cidades, com importantes reflexos no modo de viver, especialmente nas cidades de São Paulo, Santos e Campinas. Na cidade de São Paulo o quadro era especialmente complexo. A recém-implantada República via-se frente a enormes desafios. Propositor de ideais de progresso e civilização, o movimento republicano via na ciência importante instrumento de transformação e afirmação de um "novo" Brasil. No iniciar-se do novo século, era fundamental a expansão das cidades, a configuração de um sistema de transportes públicos e, fundamentalmente, o "saneamento" da sociedade. Frente às trágicas consequências de epidemias de febre amarela, cólera, varíola entre outras, cabia ao Estado buscar coordenar ações de combate às doenças, estimulando e organizando instâncias de pesquisa e ciência. Uma série de iniciativas aponta para a intenção de preparar, organizar e implementar ações concatenadas de forma a superar o impacto de tantos males sobre a economia e a população. Microbiologia, saúde pública e ações de governo se entrelaçaram. A pesquisa e instituições a ela vinculadas ganharam espaço e importância; em consequência, "intelectuais" dedicados à ciência buscavam autoridade para participar dos debates em torno de políticas públicas. Configurava-se "intelectual", conforme Sirinelli, como uma categoria socioprofissional em formação, ou seja, como "produtores e mediadores de interpretações da realidade social que possuem grande valor político" 32 . 
Museu Paulista veio integrar-se a conjunto mais amplo de instituições e serviços. Em 1891, foi criada a Academia de Medicina, Cirurgia e Farmácia de São Paulo, ainda que só efetivada com o início de funcionamento da Escola de Farmácia, em 1898 e a de Medicina, em 1913. Ainda em 1895, foi organizada a Escola Prática de Agricultura de Piracicaba e a Biblioteca Pública de São Paulo; também neste ano, o recém-fundado (1894) Instituto Histórico e Geográfico de São Paulo preparava a primeira edição de sua Revista. Entre 1890 e 1895, o Serviço Sanitário, como o Museu Paulista subordinado à Secretária do Interior, teve grande atuação, estudando microbiologia e procedimentos de combate às epidemias; constituído por diversos órgãos como o Instituto Bacteriológico, o Instituto Vacinogênico e Instituto Butantã, empreendeu ações marcadas pela combatividade e adoção de procedimentos renovados, enquanto acolhia importantes "homens de ciência" que viriam mudar o panorama das pesquisas e práticas médicas no Brasil, como Adolpho Lutz, Oswaldo Cruz, Arnaldo Vieira de Carvalho, Vital Brazil e Emílio Ribas, que também se notabilizaram na formação de alunos/pesquisadores como Carlos Chagas e Arthur Neiva. Portanto, os estudos e levantamentos de campo propostos pelo diretor do Museu Paulista, Hermann von Ihering e divulgados na Revista do Museu encontravam espaço de expressão e condições de debate científico na São Paulo do início do século XX. Questões ligadas à identidade do "povo brasileiro" dialogavam com teorias eugenistas e colocavam em discussão temas polêmicos como a inserção de índios e negros na sociedade e no mundo do trabalho. A Etnografia apresentava-se, ao lado da biologia, como meio de organização da sociedade e de definição de políticas no presente. $\bigcirc$ "cientista/pesquisador" Ihering via a Revista como locus adequado para a interação entre pares, ideal para acolher e difundir as propostas que defendia, especialmente voltadas para o mapeamento de espécies e sua relação com territórios, corroborando especulações em torno do que viria a ser formalizado, no decorrer da década de dez do dezenove, na concepção sobre a "deriva dos continentes" 33 . Para tal, considerava importante buscar intercâmbio com outros museus sul-americanos e seus pesquisadores, de forma a avançar em teorias que expressassem questões continentais. Assim, para ele, a Revista do Museu Paulista deveria trazer opiniões, sustentadas em pesquisa de campo e estudos em laboratório. Filho de um dos mais importantes juristas europeus, Rudolph von Ihering, Hermann von Ihering tinha ampla formação científica, além de beneficiar-se da inserção, em meios intelectuais europeus, da obra paterna. A marca que conferiu à publicação, de certa forma, assegurou sua continuidade, ainda que sob a direção de novos diretores-editores.

No entanto, meus questionamentos voltam-se, também, para a materialidade da publicação, dialogando, por exemplo, com propostas de estudo que buscam relacionar os textos com sua apresentação gráfica, entendendo que elas também contribuem para a "leitura", construindo e renovando sentidos. Como sugeriu Chartier,

Compreender as razões e os efeitos dessas materialidades (por exemplo, em relação ao livro impresso o formato, as disposições da paginação, o modo de dividir o texto, as convenções
33. A teoria sobre a "deriva dos continentes", baseada no formato dos continentes, especialmente América do Sul e África, foi primeiramente divulgada no livro de $1915, A$ origem dos continentes $e$ oceanos, de Alfred Weneger. A ideia vinha sendo debatida desde o final do dezenove; propunha que há $200 \mathrm{mi}$ lhões de anos todas as massas emersas da Terra estariam reunidas em um único supercontinente, denominado Pangea. Posteriormente essa massa continental teria se fraturado em partes menores que se dispersaram em consequência de movimentos horizontais. Para sustentar suas hipóteses, Wegener buscou evidências geológicas paleontológicas e climáticas. As pesquisas de Ihering caminhavam nesta direção e buscavam indícios de sustentação semelhantes. Ver: <www.ibge.gov.br> www. ibge.gov.br, no link memória institucional, acesso em 31 de agosto de 2011 
que regem a sua apresentação tipográfica, etc.) remete necessariamente ao controle que editores ou autores exercem sobre essas formas encarregadas de exprimir uma intenção, de governar a recepção, de reprimir a interpretação. ${ }^{34}$

Entendo, portanto, que a capa da Revista, primeiro contato do leitor com a publicação, pode ser analisada enquanto espaço de informações importantes que contribuem para problematizar diferentes questões como intenções dos editores, características do público leitor ou condições da indústria gráfica. Forma de apresentação da Revista, a capa trazia a identidade que se propunha conferir à publicação, de acordo com padrões estéticos reveladores de gosto de segmentos da população - seu público leitor, assim como as formas de produção gráfica disponíveis.

Em sua materialidade, a Revista do Museu Paulista foi apresentada ao público leitor como brochura, no formato $8,16 \mathrm{~cm} \times 24 \mathrm{~cm}$, em cadernos de quatro folhas, com capa dura. Um dos itens fundamentais da capa, porque a ele se conferiu relevante destaque gráfico, está no ano de publicação, pelo qual se pode aferir a regularidade da produção das edições. Percebe-se, assim que a periodicidade de apresentação dos exemplares ao público variou; em média temos uma edição a cada dois anos - quando isto não acontecia, os editores cuidavam de justificar o intervalo entre as publicações o que contribui para a hipótese de que a bianualidade fosse a expectativa para a circulação dos volumes, ainda que tivéssemos uma edição em 1897 e outra em 1898 e, com a chegada de Taunay à direção, um esforço para diminuir os intervalos de publicação com uma sequência anual de volumes para 1918, 1919 e 1920; 1926 e 1927; 1931 e 1932. Possivelmente buscando apresentar-se de forma erudita e consistente à comunidade a qual se dirigia, as edições traziam exemplares bastante volumosos; no entanto, não se faz referência nas capas ao número de artigos ou páginas. Interessante destacar que, durante a gestão lhering, a Revista foi apresentada em volume; com a chegada ao Museu Paulista de Affonso Taunay, o novo editor, como as capas deixaram registrado, preferiu usar tomo, evidenciando outro momento da publicação.

Ainda que, especialmente nas edições de 1 a 9, predominasse a produção de Hermann von lhering, seu editor, a Revista abriu suas páginas para a produção de muitos cientistas de destaque, brasileiros e estrangeiros com pesquisas no Brasil, que enviavam seus artigos de São Paulo, Rio de Janeiro e, com alguma frequência, de Buenos Aires.

A seguir, apresento quadro com os números da Revista, editor, data de publicação, número de páginas e números de pranchas, ou seja, ilustrações (desenhos e/ou fotos; branco e preto e/ou coloridas) - aspecto apontado pelos editores como fundamental para publicação científica e que, pelo custo, representava uma distinção, tanto do ponto de vista científico como gráfico. 


\begin{tabular}{|l|c|c|c|c|}
\hline \multicolumn{1}{|c|}{ Edição } & Ano & Editor & Páginas & Ilustrações \\
\hline Volume I & 1895 & H. von Ihering & $253 \mathrm{p}$. & 3 pranchas \\
\hline Volume II & 1897 & H. von Ihering & $495 \mathrm{p}$. & 9 pranchas \\
\hline Volume III & 1898 & H. von Ihering & $568 \mathrm{p}$. & 7 pranchas \\
\hline Volume IV & 1900 & H. von Ihering & $600 \mathrm{p}$. & 14 pranchas \\
\hline Volume V & 1902 & H. von Ihering & $755 \mathrm{p}$. & 18 pranchas *** \\
\hline Volume VI & 1904 & H. von Ihering & $679 \mathrm{p}$. & 23 pranchas \\
\hline Volume VII & 1907 & R.von Ihering* & $555 \mathrm{p}$. & 13 pranchas \\
\hline Volume VIII & 1911 & H. von Ihering & $582 \mathrm{p}$. & 7 pranchas \\
\hline Volume IX & 1914 & H. von Ihering & $534 \mathrm{p}$. & 9 pranchas \\
\hline Tomo X & 1918 & Taunay & $1028 \mathrm{p}$. & 49 pranchas \\
\hline Tomo XI & 1919 & Taunay & $944 \mathrm{p}$. & 42 pranchas \\
\hline Tomo XII & 1920 & Taunay & $936 \mathrm{p}$. & 34 pranchas \\
\hline Tomo XIII* & 1922 & Taunay & $1333 \mathrm{p}$. & 36 pranchas \\
\hline Tomo XIV & 1926 & Taunay & $840 \mathrm{p}$. & 50 pranchas \\
\hline Tomo XV & 1927 & Taunay & $1038 \mathrm{p}$. & 40 pranchas \\
\hline Tomo XVI & 1929 & Taunay & $1033 \mathrm{p}$. & 37 pranchas \\
\hline Tomo XVII \\
(1a Parte)
\end{tabular}

Edições da Revista do Museu Paulista

* Rodolpho von Ihering, filho de Hermann von Ihering, Custos do Museu Paulista e diretor interino, durante viagem de seu pai e diretor da instituição à Europa.

* * Tomo Comemorativo do Primeiro Centenário da Independência Nacional. Neste mesmo ano, nasceu Annaes do Museu Paulista, segunda publicação do Museu Paulista, vinculada à seção de História, recémcriada pelo Diretor Affonso d'Escragnolle Taunay e também sob sua direção.

*** Este número da Revista apresentou-se como Catálogo das Aves do Brasil; ainda no mesmo ano publicouse o tomo XXIII da Revista do Museu Paulista.

**** Nesta edição, aparecem as primeiras pranchas coloridas -7 litografias apresentando estudo sobre insetos, preparadas em Frankfurt, de grande beleza gráfica.

Durante todos os anos de publicação da Revista, a capa trouxe, em blocos, dispostos em planos geométricos, o nome da publicação, uma imagem do Museu Paulista, o número do exemplar e o ano de impressão. A capa propõe, desta forma, em função da sequência dos títulos e imagens que organiza e 
dispõe, não só uma hierarquia a sugerir níveis de importância conferidos por posição, tamanho e ordem das diferentes inserções, como visões e demandas que acompanharam a trajetória da Revista. Cabe, assim, refletir sobre a pertinência da análise da capa na recuperação, na visão do editor, do que deveria ser enfatizado ou destacado, na publicação. Neste sentido, a chegada de Affonso Taunay à direção do Museu e, consequentemente, à posição de editor da Revista, traz nova diretriz, ou seja, a supressão do nome do editor de sua capa. Da mesma forma, a vinculação do Museu Paulista à Universidade de São Paulo, a partir de 1935, também receberá indicação na capa, encabeçando a apresentação da Revista - e mantendo-se presente nas demais edições que se sucederam. Portanto, para o leitor atento, é possível recuperar "de capa" momentos da publicação e, por desdobramento, reformulações na vida cultural paulista. A condição de "fonte" a ser explorada no estudo destas capas ganha contornos melhor definidos, considerando-se possibilidade de identificar e reconhecer movimentos de afirmação de prestígio que nelas ganharam visualidade. Preparálas, certamente, constituía desafio. Caberia a elas conferir identidade à instituição, assegurar prestígio a seu editor e colaboradores e fazer reconhecer a pertinência da Revista no espaço editorial em que se inseria e com o qual dialogava.

Assim, com data de edição de 1895, o volume I da Revista do Museu Paulista saiu do prelo em janeiro de 1896 (Figura 1). Como o primeiro volume,
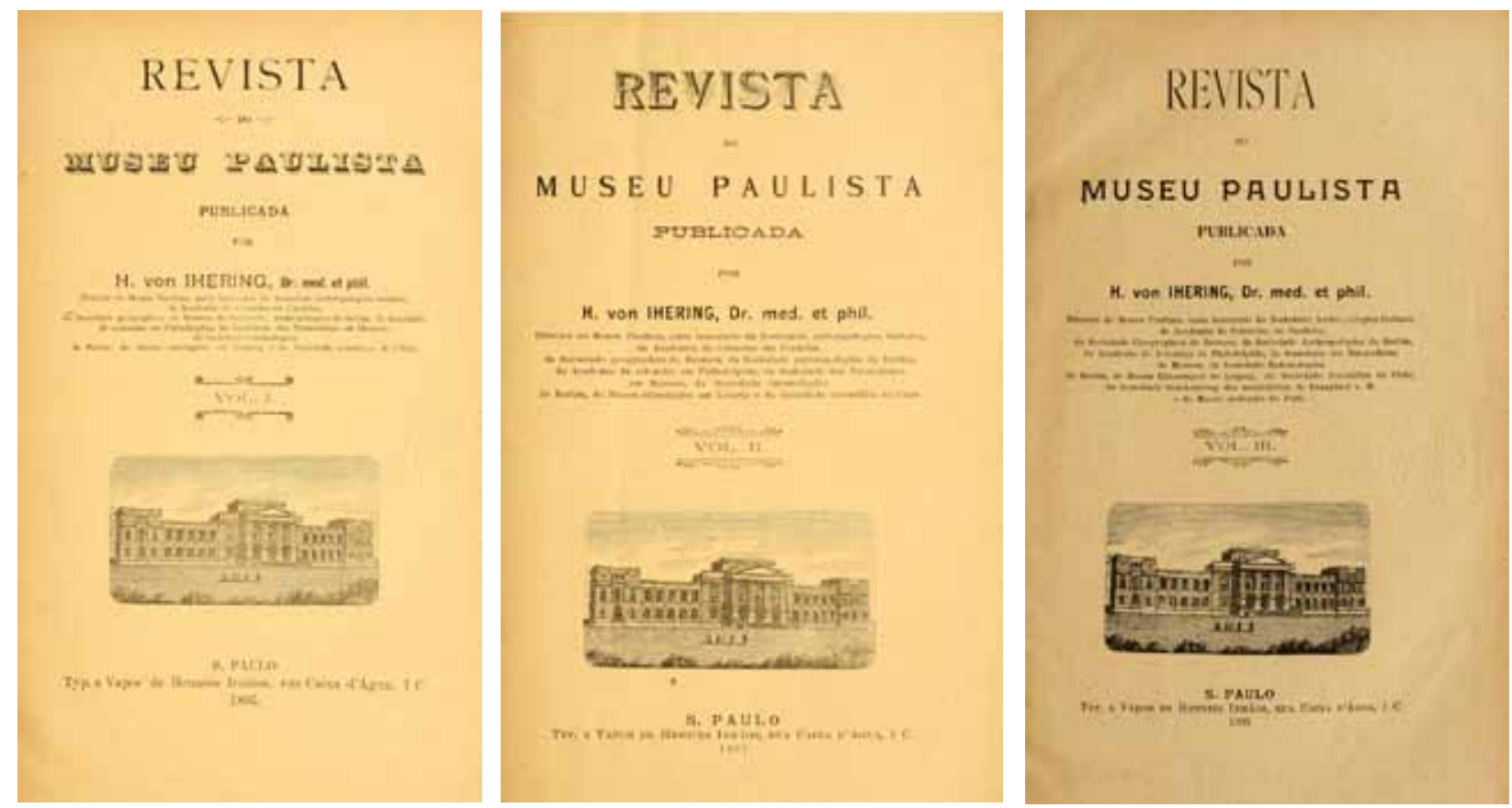

Figuras 1 a 3 - As três primeiras capas da Revista do Museu Paulista $(1895,1897,1898)$ durante gestão lhering, editadas pela Typographia a Vapor de Hennies Irmãos, R. Caixa d'Água, 1C, São Paulo. 
seus dois números seguintes foram impressos pela mesma casa tipográfica (Figuras 2 e 3). Ihering buscou, para os serviços de editoração e impressão da Revista ${ }^{35}$, o que havia de mais competente em São Paulo: a Typographia a Vapor de Hennies e Irmãos. Correspondência preservada no Fundo Museu Paulista dá conta das dificuldades que o diretor encontrou em manter a impressão da Revista aos cuidados da Hennies e Irmãos, sua escolha pessoal, enquanto o governo do Estado buscava, alegando questões orçamentárias, garantir a transferência da impressão pelo Diario Official ${ }^{36}$ o que virá a ocorrer a partir do número $4^{37}$, da Revista.

Será mais conveniente este modo de publicação do que o pelo Diario Official, visto que as diversas qualidades de typos, de clichês etc. me obrigam a ser muito exigente especialmente nos correctivos e que posso ser mais rigoroso com uma casa que será paga do que com a repartição que há muito que fazer e não trata desta como de questão principal como eu a quero ${ }^{38}$.

A impressão destes volumes é trabalho de qualidade para diferenciar a publicação e acentuar seu caráter pioneiro, na cena cultural paulista. A competência em manejar a litografia é recurso que lhering vai procurar usar, associando imagens aos textos, na Revista. Portanto, pode-se entender que, para o editor, a função "ilustrativa", na relação texto/imagem, era dimensão a ser exercitada. Ainda que não seja adequado definir um estilo para as opções gráficas desenvolvidas, percebe-se a permanência do ecletismo com elementos artísticos em molduras e vinhetas. Contando com o trabalho gráfico desenvolvido por Hennies \& Irmãos, foi possível elaborar e apresentar arranjos visuais que ainda se valiam das habilidades de mestres tipógrafos. Portanto, estas capas da Revista permitem acompanhar o rico diálogo entre "artes de fazer" e "formas de produzir", estágio em que o caráter artesanal da tipografia sofria, na passagem do século dezenove para o vinte, expressivo movimento de transformação, impondo-se adequações que espelhavam a mecanização e automatização dos trabalhos. A qualidade dos editores-tipógrafos pode ser observada, por exemplo, em vinheta (Figura 4), associando ao texto a sofisticação de elementos decorativos.

Peço a atenção do leitor para os três blocos de informação, presentes nas capas, que considero básicos para análise, em função inclusive de sua permanência e/ou transfiguração nas sucessivas edições: o título da publicação; a presença/ausência do editor e a referência institucional. Ainda que o número VII tivesse como editor o filho de lhering, o também pesquisador-naturalista Rudolph von Ihering, entendia-se, como fica claro no Prefácio da Revista, que eram as orientações deixadas por "Ihering pai" que norteavam as escolhas editoriais do número enquanto expressão de "continuidade" de produção, a ser preservada e defendida.
35. A qualidade dos serviços da tipografia aliada ao cuidado com a modernidade dos equipamentos foi comentada por Ana Luiza Martins: "Em busca dos últimos lançamentos do mercado, coube aos irmãos Henrique eTheodoro Hennies instalar a primeira fábrica no Brasil de cartões de fantasia em alto relevo e importar o que havia de mais moderno no campo tipográfico e litográfico.", Cf. Martins (2001, p. 189). Esta relação da Hennies e Irmãos com a excelência técnica é expressa, inclusive, em sua apresentação, por meio da identificação da tecnologia que empregava em suas atividades: "a vapor".

36. Américo Brasiliense, nomeado para o governo de São Paulo pelo mal. Deodoro da Fonseca em 07/03/1891 cuidou, entre suas primeiras iniciativas, da criação da Typographia do Estado, decreto 162 de 28/04/1891, para lançar, entre outras publicações o Diario Official do Estado. Ver Maranhão (1994).

37. A impressão da Revista apenas para o volume de 1907 , quando esteve à frente da instituição Rudolph von Ihering, foi realizada fora do Diario Official, pela Typographia Cardozo, Filho e C.. Na ocasião, se preparava uma reformulação das oficinas da imprensa do Estado e, por decisão do governador,Jorge Tibiriça, a impressão de obras ficou, provisoriamente, suspensa. Ver Maranhão (1994).

38. Fundo Museu Paulista, P. 93, 18/07/1895. 


\section{0 mused padlista no anNo DE 1896}

หมพ

\section{Dr. H. von Ihering}

O primeiro volume desta Revista sahí do prolo no mez de Janeiro de-1896, ruzão porg̨ue as no corronte anno apparece a segundo volume. Nín pretendo repetir o que consta dos relatorios que aprescutel em principios de 1896 o de 1897 an Exm. Snr. Dr. Sectotario do Inter rior. Algumas expliencoes, porém, a respeito do serviço no anno passado så necessarias aqui.

Eutre as experficốc que muito contribuiram para augrmentar as collecgoes do Mnseu mereseem mençáo es-

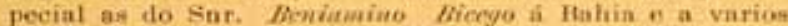
lugares no interior deate Rintado (Sorocala, Cerqueira Cezar perto de Botucatii, Itapetiningra) e a do Sur. Jevio Zech an Piquete a Serra da Mantiqueira. Nlem disto fiz, accompantado dos preparadores Sure. H. Pinder of B. Bicego, uma excursalo ao unuieipio do S. Sebastiño e. If ilha do mestno nome. Espero que, em benetieio do Museu, seja pessivel organisar un illa de \&. Sebastino umn estaçón biologica, o toutoi favel-0 por mens proprion meioe, não podendo, porom, realitar in compra do um predio afim de installar a referida extação por motivon indopendentes do minha vontade.

Figura 4 - No topo da página, vinheta ricamente decorada apresenta o Relatório do Diretor, em 1916. Revista do Museu Paulista, v. 1, 1895.

título da publicação

Para facilitar e ampliar a leitura das capas, apresento, nas Figuras 5 a 9 , o conjunto de imagens que reúne os volumes editados sob a responsabilidade de Hermann von thering.

Quanto ao primeiro bloco de informação expresso no título, "Revista do Museu Paulista", percebe-se que a continuidade editorial vai enfatizando, graficamente, o nome da instituição - Museu Paulista - a sugerir que, paulatinamente, aquela vai se constituindo como principal referência para a Revista. É possível observar que o nome da publicação foi apresentado e mantido como primeira informação oferecida ao leitor, no correr das edições. 

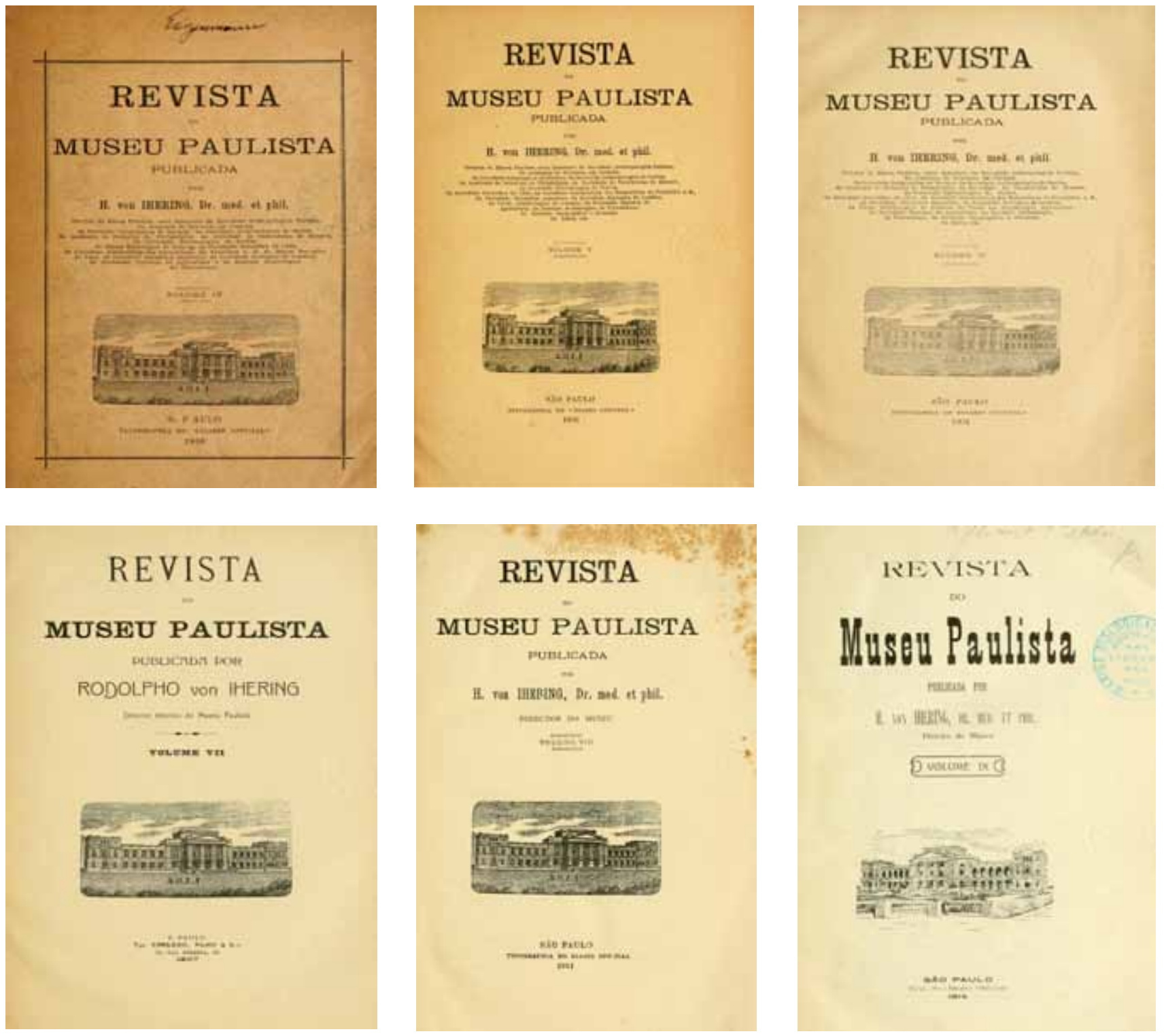

Figuras 5 a 9 - Capas da Revista do Museu Paulista, volumes IV(1900), V (1902), VI (1904), VII (1907), VIII (191 1 ) e IX (1914).

No entanto, os tipos da impressão assinalam mudanças enquanto 39.Ver Chartier (1999, p. 40). indicam possibilidades múltiplas de leitura - na primeira capa, o destaque está na instituição: Museu; na segunda, em Revista e, na terceira, ainda que o nome da instituição esteja realçado, há uma espécie de equilíbrio, sugerindo que Revista do Museu Paulista havia conquistado identidade própria, ou seja, como considerou Chartier", "havia se consolidado não só pelas ideias que veiculava, mas por sua forma", isto é, pela maneira particular como o autor produziu, reuniu e exprimiu os conceitos que apresentava. Há de se destacar que os tipos sugerem sofisticação 
e requinte, transferindo para a publicação não só zelo e cuidado na produção, mas sua vinculação a público diferenciado e culto. $\bigcirc$ cuidado na capa apontava para a riqueza a ser encontrada em suas páginas, em diálogo com as demandas que sustentavam a necessidade de qualidade gráfica nas publicações "científicas", ou seja, a importância do "ver", também característica dos trabalhos em museu. Fica evidente que a preocupação com a forma atestada, por exemplo, pela relação tensa com as oficinas de impressão, identificada na correspondência pessoal, primeiramente de lhering e mais tarde de Taunay e preservada no Fundo Museu Paulista, também pode ser analisada enquanto anseio de uma qualidade que se deve apresentar ao leitor em belos tipos, em bom papel e correta composição de textos e ilustrações - sugerindo tentativas de domínio sobre a produção e transmissão de ideias e projetos. Desta forma, autor (no caso editor) e obra se entrelaçavam, numa relação mútua de prestígio e qualidade de produção intelectual.

Em consonância com o projeto de organização do Museu, defendido por Ihering, que propunha a formação de coleções como instrumento para a produção de saberes e, por decorrência, a afirmação da autoridade dos professores-cientistas na sociedade, a Revista expressava e reforçava intenções, dialogava com propostas e as desenvolvia em movimento complexo, na medida em que, em conjunto com colaboradores, dava origem a uma "comunidade de cientistas-especialistas" envolvidos com projetos de nação. Viajantes-naturalistas colaboravam com a Revista, contribuindo para processo de apossamento de território pelo conhecimento de sua natureza - fauna, flora, geografia e geomorfologia. "Ver" como corolário de "conhecer", enquanto condição de configuração de individualidade da nação, que assim, por meio de suas especificidades, encontrava formas de legitimação.

Também eram temas de divulgação, questões postas por teorias científicas e que expressavam movimento de civilização, pela Europa, de novos continentes - o "fardo do homem-branco". A contribuição de cientistas de origem europeia, naquele momento, conferia distinção à publicação. Posteriormente, esta presença será objeto de críticas, uma vez que, especialmente nos anos 20 e 30 do século passado, novas concepções denunciaram "desnacionalização", ou seja, descaso com reserva de espaço para pesquisadores "brasileiros", pela atuação destes "estrangeiros". Em 1937, colaborador da Revista, Mello Leitão, zoólogo do Museu Nacional, fez memória do período e considerou:

De 1895 a 1914 publicou H. von Ihering nove volumes da Revista do Museu Paulista nos quais, além de sua farta contribuição pessoal, há a colaboração de Ameghino, J. Bach, Telêmaco Borba, J. Brethes, H. Brolemann, Cockerell, A. Duche, C. e A. Eigenmann, Carlos Euler, Foetterle, A. Hempel, R. von lhering, F. Iglesias, E. Kayser, G. King, H. Luederwaldt, A. Lutz, W. Moenkhaus, Fritz Mueller, Longinos Navás, A. Ortmann, Schrottky, Schupp, Smith-Woodward, H. Sutter, Wasmann e Weise, ou sejam, entre 27 colaboradores, apenas três 
brasileiros! De 1916 a 1937 publicou A. de Taunay 11 volumes, com as memórias de 62 colaboradores. Froes de Abreu, M. Tenorio do Albuquerque, Afrânio Amaral, Henrique Aragão, H. Baldus, Gregorio Bondar, F. Borgmeier, Alfredo de Carvalho, Livino de Carvalho, A. Childe, Julio Conceição, A. Ducke, Amaro van Amelen, H. Florence, Pinto da Fonseca, E. Garbe, J. Florencio Gomes, Guimarães Jor., Adolfo Hempel, Fred. Hochne, E. Holt, A. Hummel, R. Kleine, Mello Leitão, Paes Leme, Leonardo Lima, H. Luedenvaldt, Mario Melo, Julio Melzer, Longinos Navás, J. T. Nichols, Clemente Pereira, Cesar Pinto, Napoleão Reis, Miranda Ribeiro, A. M. Sala, A. Sampaio, Santochi, Schrottky, Schfeldt, Álvaro da Silveira, F. Sommer, Pirineus de Souza, C. Tastvin, A. d'E. Taunay, C. Townsend, Lauro Travassos, Treadswerl, Val Floriano, Plínio Airosa, Almeida Braga, Leonardo Lima, Oluvério Pinto, Cunha Vieira, Olarla, Camargo Andrade, J. e F. Lane, R. Spritz, L. R. Guimarães, Morais Rego, Barros Erhardt, H. Baldes ${ }^{40}$.

A recuperação destas dimensões, no entanto, ainda que ancorada, basicamente, na textualidade, pode também ser compreendida no "trabalho" do editor, que tem na formatação da capa etapa fundamental por se constituir em primeiro objeto de comunicação editor-leitor. Sua apresentação de forma primorosa indicava, por um lado, relação que se consolidava no interior da publicação pela atuação, sob a liderança do editor, de um grupo de "cientistas" e, ao mesmo tempo, a projeção de sua produção intelectual, individual e coletiva, junto a forças sociais e políticas com as quais dialogava. Certamente, especialmente pela repercussão de alguns dos artigos nela publicados, é possível buscar público receptor que incluía não só os que se sentiam representados pelas posições assumidas, mas, da mesma forma, aqueles que delas discordavam e que deveriam conhecê-las, para as combaterem. A dimensão "fórum" entre pares contribui para o reconhecimento da importância da Revista, sem negligenciar outros espectros no grupo leitor. A produção científica no e do Museu Paulista expressava-se por meio de sua publicação.

Ainda que, a partir do número $X$, a responsabilidade pela formatação da Revista passasse a cargo do novo diretor nomeado - Affonso d'Escragnolle Taunay - o título da publicação, no alto da capa e, basicamente, como primeiro bloco de informação, veio a permanecer. Como já mencionado, Taunay optou por mudar as indicações de publicação de "volume" para "tomo". No entanto, nos primeiros exemplares da Revista em sua nova fase, a capa vem com grande economia de informações, talvez sugerindo especialmente momento de transição da própria instituição frente a demandas sociais renovadas. $\bigcirc$ principal destaque ficou para a indicação do Museu, em tipo diferenciado e negritado, associado à indicação "Revista" (Figuras 10 e 11). A abertura do tomo X se dá por meio de uma Advertência do editor/diretor que então assumia, o que contribui para corroborar estas impressões e apontar para uma retomada de propósitos e atividades.
40. Cf. Leitão (1937 p. 193), grifos meus. Interessante notar que, na mesma linha de considerações de Mello Leitão, Affonso Taunay (1946) também cuidou de construir memória sobre a Revista do Museu Paulista. 
REVISTA

130

\section{JUSHU PHUIISTH}

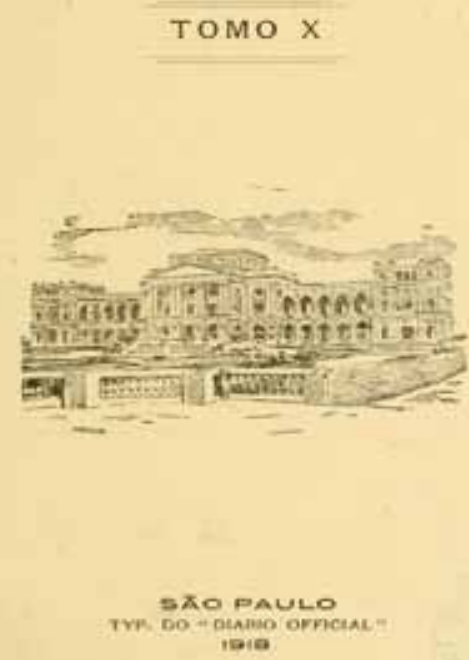

\section{REVISTA}

150-

\section{JUISHU PHUIISH}

TOMO $\mathrm{XI}_{1}$

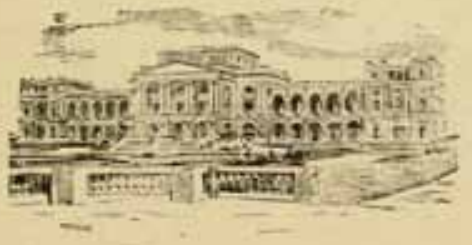

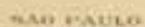

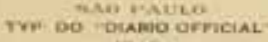

inio

Figuras 10 e 11 - A Revista do Museu Paulista, tomo X (1918) e tomo XI (1919), já sob a direção de Affonso Taunay.

41. Cf.Taunay (1918).

42. Idem.

\section{ADVERTÊNCIA}

Após uma interrupção de quatro annos reapparece a Revista do Museu Paulista. Foi esta pausa motivada por múltiplas circunstancias, sobretudo pelo período anormal pelo qual, em 1915 e 1916, passou o Museu, com a sua vida regular suspensa pelos trabalhos do inquérito administrativo a que nelle se procedeu e, como consequência, the trouxe a mudança de direcção. ${ }^{41}$

Especificamente em relação à Revista, Taunay ainda considerou importante destacar, nesta mesma seção:

Apenas empossado da Directoria do Museu cogitamos imediatamente da organização de um tomo da Revista que havia mais de três annos não se editava. Assim, pondo-nos a campo tratámos de angariar, e com a maior rapidez, elementos para um numero de quinhentas paginas. Tornava-se necessário demonstrar ao publico, em geral, e sobretudo aos Institutos do Universo, em relação com o nosso, que a vida scientifica do Museu Paulista recomeçara. ${ }^{42}$ 
Portanto, o "demonstrar ao público em geral", a se considerar a economia de informações e detalhes da capa, mais parecia um projeto em busca 43. Ver Meneses (1994, p.577). de novo formato.

A íntima relação entre a capa e os acontecimentos que cercaram sua produção é mais uma vez reforçada no tomo XIX: a criação da Universidade de São Paulo, antiga reivindicação de amplos setores da sociedade paulista. A condição de "instituto complementar" à Universidade foi imediatamente incluída na capa, em posição de destaque. Ainda que, como sugeriu Ulpiano, em nota a artigo 43 para a revista Estudos Avançados, "ao se criar a Universidade de São Paulo, em 1934, o Museu Paulista foi declarado seu instituto complementar, o que, entretanto, nunca teve efetiva significação", é de se considerar que esta nova condição, ao ser claramente explicitada, em função do destaque que veio a ganhar na formatação da capa da publicação do Museu, quando encabeça as informações levadas ao leitor, mostrou outra situação (Figura 12).

Cabe, tendo em vista a ainda condição de formação da Universidade, em movimento de fundação, frente à "tradicional" publicação do Museu Paulista, cogitar sobre uma transferência de prestígio e, especialmente, em ação

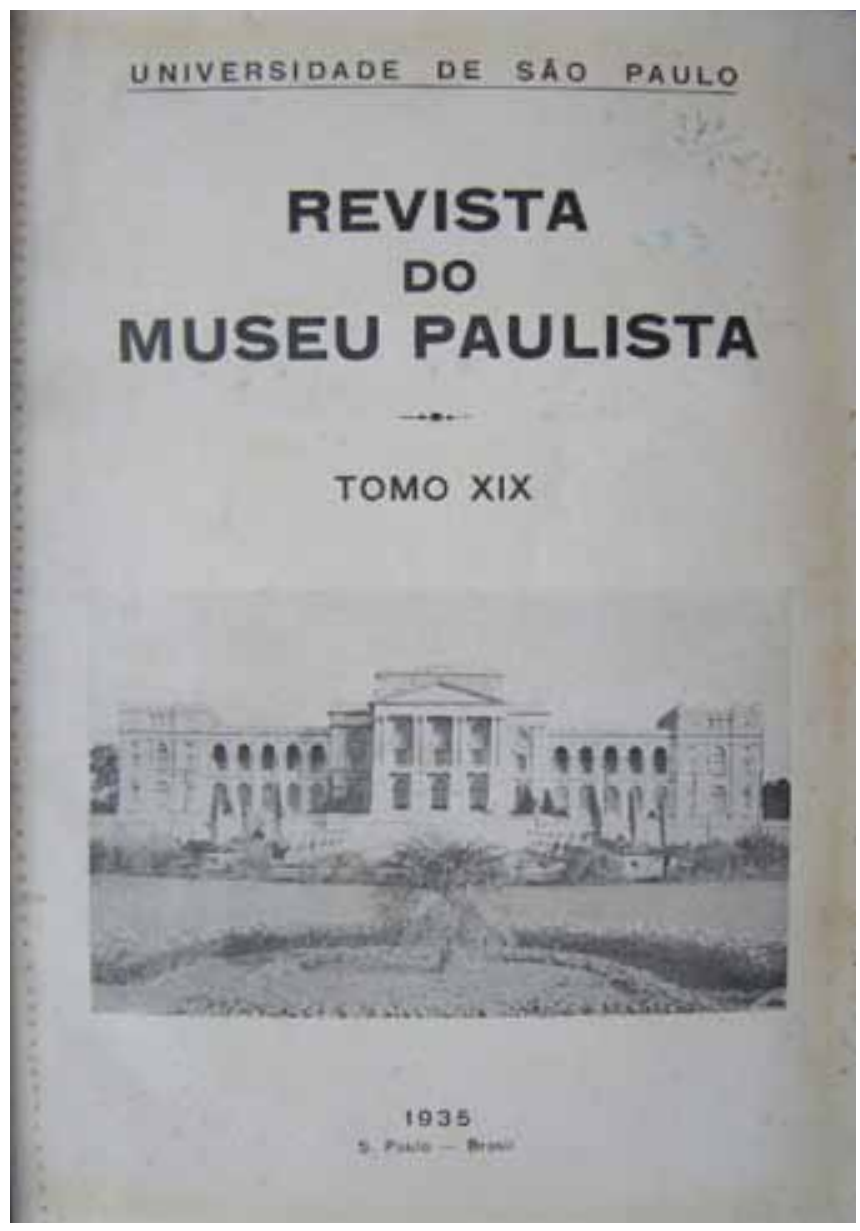

Figura 12 - Capa da Revista do Museu Paulista, tomo XIX (1935), já estabelecendo relação com a Universidade de São Paulo, recém-criada. 
concertada, que sugeria a atuação de grupos políticos na cena paulista. A presença em capa da Universidade de São Paulo expressava, muito possivelmente, não só aspiração de distinção na atividade científica, mas associação a valores paulistas, como o pioneirismo, a liderança para o progresso nacional, assim como a presença (e importância) do Museu Paulista, neste movimento: questões em debate na década de 30, do século vinte. No entanto, deve-se reconhecer a ênfase conferida na relação "revista/Museu Paulista", pela opção por tipo negritado e de maior peso visual. Se um diálogo entre instituições se iniciava, a capa sugeria que o editor da Revista procurava destacar a solidez do Museu le de suas publicações) sustentada no peso de uma tradição que vinha desde 1895 , renovada nos anos de 1920, e pretendia, ainda que em associação, preservar espaços e condições. As mudanças sociais e políticas no cenário paulista, convulsionado primeiramente pela revolução Constitucionalista de 1932 e, em seguida, pelo movimento em torno da reconfiguração dos embates políticos sugeridos pela Constituinte de 1934, não poderiam negligenciar as tradições de passado que reivindicava reconhecimento e respeito, da mesma forma que convinha ao Museu Paulista e sua Revista reconhecer a emergência de novos protagonistas e, com eles, entretecer relações, de forma a assegurar espaços arduamente conquistados.

Oeditor

A publicação de uma "revista" que divulgasse as atividades do Museu Paulista, como já mencionado, estava prevista no próprio regulamento para a formação da instituição.

No entanto, é necessário reconhecer que, na São Paulo de 1895, a circulação de periódico "científico" ainda se constituía em experiência inovadora que dependia da formação de uma comunidade de leitores. Portanto, também fazendo uso da capa, o autor-editor que de forma tão cuidadosa preparava a Revista, expôs sua vinculação à publicação para se apresentar. Em movimento circular de afirmação de competência e intenção de reconhecimento, Hermann von Ihering pôde viabilizar associação entre a publicação e seu nome e, muito provavelmente, ir assinalando, por meio de suas relações pessoais e institucionais, a ampliação do raio de atuação do periódico ao qual, tão intensamente, se dedicava.

No volume I (ver Figura 1), Ihering apresentou suas qualificações pessoais: "doutor, médico e filósofo", indicando uma formação ampla, que se estendia das ciências naturais à humanidade, expressando concepção de "cientista" em que a especialização disciplinar ainda não havia totalmente se firmado. Para, em seguida, especificar suas relações na comunidade científica. Neste movimento, procurou evidenciar sua posição reconhecida em comunidade internacional, onde se inseria e com a qual partilhava experiências, a servir tanto 
como argumento de autoridade para ampliar a circulação da Revista, como para sugerir, a possíveis rivais, respeito e aceitação para seu trabalho. Assim, na capa, logo em seguida ao título do periódico, foram apresentadas as seguintes "informações" para o leitor:

\title{
PUBLICADA \\ POR
}

H. von IHERING, Dr. med. et phil.

Director do Museu Paulista, socio honorário da Sociedade

anthropologica italiana, da Academia de sciencias em Cordoba, da

Sociedade geographica de Bremen, da Sociedade anthropologica de

Berlim, da Academia de sciencias em Philadelphia, da Sociedade dos

Naturalistas em Moscow, da Sociedade entomológica de Berlim, do

Museu etnológico em Leipzig e da Sociedade scientifica do Chile.

No volume III (ver Figura 3), novas informações foram agregadas de forma a atestar uma "evolução", da publicação e de seu editor, expressa na expansão da comunidade em que atuava, o que vinha colaborar para a afirmação de crescimento de prestígio, atraindo colaboradores e leitores.

\author{
PUBLICADA \\ POR \\ H. von IHERING, Dr. med. et phil. \\ Director do Museu Paulista, socio honorário da Sociedade \\ Anthropologica Italiana, da Academia de Sciencias em \\ Cordoba, da Sociedade Geographica de Bremen, da Sociedade \\ Anthropologica de Berlim, da Academia de Sciencias de \\ Philadelphia, da Sociedade dos Naturalistas de Moscow, da \\ Sociedade Entomologica de Berlim, do Museu Ethnologico de \\ Leipzig, da Sociedade Scientifica do Chile, da Sociedade \\ Senckenberg dos naturalistas de Frankfurt a. M. e do Museu \\ zoológico do Pará.
}

Interessante observar, por esta capa, que somente no número III da Revista uma instituição científica "brasileira" é mencionada - o Museu Zoológico do Pará - confirmando as estreitas relações entre lhering e o então diretor do Museu Zoológico do Pará (1894/1907), Emil Goeldi, "cientista" suíço, que, como ele, exercera a função de naturalista viajante no Museu Nacional.

Em 1902, o volume V (ver Figura 6) já indicava uma ampliação das conexões da Revista, transcendendo parcerias exclusivamente pessoais e indicando o fortalecimento de outras instituições semelhantes, no Brasil. Neste momento, já a Bahia e Pernambuco dialogavam no interior desta "comunidade", sugerindo, inclusive, o desdobramento e o enriquecimento dos debates. 


\section{PUBLICADA}

POR

H. von IHERING, Dr. med. et phil.

Director do Museu Paulista, socio honorário da Sociedade

Anthropologica Italiana, da Academia de Sciencias em Cordoba, da Sociedade Geographica de Bremen, da Sociedade

Anthropologica de Berlim, da Academia de Sciencias de

Philadelphia, da Sociedade de Naturalistas de Moscow, da

Sociedade Entomologica de Berlim, da Sociedade Scientifica do

Chile, da Sociedade Senckenberg dos Naturalistas de Frankfurt a.

M., da Sociedade Scientifica Argentina, da Sociedade Zoológica

de Londres, da União Ornithologica de Londres, da Sociedade

Nacional de Agricultura, do Instituto Archeologico de Pernambuco,

do Instituto Geographico e Histórico da Bahia, etc.

O volume seguinte (ver Figura 7), publicado em 1904, praticamente consolidando uma década de circulação da Revista, trouxe também, como parceira, a União Ornitológica Americana, o que vem assinalar a ampliação de pesquisas, da Europa (como atestava a presença de instituição semelhante, sediada em Londres, mencionada no volume anterior) para a América, em movimento de difusão, mas, também, de "civilização" e "progresso" das nações sul-americanas.

De modo instigante, a Revista do Museu Paulista viveu, entre 1904 e 1907, um hiato maior de publicação. O número VIl saiu três anos após o anterior e trouxe na capa um momento específico da instituição - seu diretor estava em viagem para a Europa. Desta forma, seu filho e auxiliar, assumia a edição da Revista, apresentando-se como "Diretor interino". O Relatório que abriu a publicação trouxe informações que demandam leitura cuidadosa: dificuldades na instituição, os esforços para reunir material de publicação, a necessidade de recursos para manter e aperfeiçoar o museu e uma espécie de "missão", na viagem do diretor - buscar na Europa experiências de outras instituições congêneres. Pode-se, portanto, aventar a possibilidade de que os rumos que Ihering buscava imprimir ao Museu encontravam opositores o que o obrigava a buscar apoio, legitimando suas intenções - como, aliás, se pode observar em artigo do volume seguinte - o número VIII, publicado em 1911. Nele, lhering relatou seus encontros na Europa e defendeu uma proposta de perfil institucional, inspirado no que vira no "mundo civilizado". A leitura do Relatório deste número explicitou situação já delineada na capa: as dificuldades do diretor em preservar suas funções. Em consequência, ainda que muitos serviços tenham sido apontados, como a organização de exposições ou a produção de inúmeros artigos, o texto do Relatório vinha em tom sombrio e, ao mesmo tempo, reivindicador. A seguir os volumes (ver Figura 8 e 9) VIII (1911) e IX (1914) trouxeram, apenas: 
POR

H. von IHERING, DR. MED. ET PHIL.

Director do Museu

De certa forma, o que vinha se enunciando concretizou-se: o afastamento de lhering, em 1915, com a nomeação de um grupo de interventores com a função de conduzir inquérito administrativo. A gestão lhering chegava ao fim. Após um curto intervalo em que o Museu permaneceu sob a direção de Armando da Silva Prado (empossado em agosto de 1916), como resultado de complexas gestões, sugeridas pela documentação preservada no Fundo Museu Paulista, o governo do estado nomeou Affonso d'Escragnolle Taunay para a função (fevereiro de 1917).

Mais uma vez, coube à Revista registrar estes movimentos. $\bigcirc$ "director em comissão", em Advertência, no volume $X$, ao assinalar a interrupção de quatro anos da publicação, ainda que procurasse apontar para o encerramento de uma etapa com sua filosofia de trabalho, cuidou de justificar procedimentos, procurando sustentar suas iniciativas.

Após uma interrupção de quatro annos reaparece a Revista do Museu Paulista. Foi esta pausa motivada por múltiplas circumstancias, sobretudo pelo período anormal pelo qual, em 1915 e 1916, passou o Museu, com a sua vida regular suspensa pelos trabalhos do inquérito administrativo a que nelle se procedeu e, como consequência, the trouxe a mudança de direcção. Alem desta ordem de questões de vida interna, occorreram os longos e laboriosos tramites do inventario, geral e minuciosissimo, procedido em todas as colecções do Ypiranga, por ordem do Governo do Estado de São Paulo ${ }^{44}$.

Nesta primeira edição sob sua responsabilidade, Taunay buscou não só apresentar-se como assinalar os "apoios" que havia recebido. $\bigcirc$ "novo diretor" também propunha uma "nova" Revista, e, sugestivamente atribuía ao antecessor um perfil muito especializado à publicação, que deveria ser ampliado, ao declarar que "nela publicaremos, sem distinção especial, contribuições que se refiram não só a todas as ciências naturais como à biologia, em geral, e à arqueologia paulista". Observando-se a capa do tomo X (ver Figura 10), nota-se que, muito possivelmente em função das dificuldades com as quais a instituição se defrontava, se preferiu omitir a identificação do editor. Por outro lado, em seu interior, o novo diretor se dava a conhecer, confessava sua inexperiência para a função, expressava seu interesse e dedicação e atribuía à Revista papel expressivo no que ele pretendia enfatizar: a nova fase do Museu Paulista, sustentada em novos parceiros, convidados a colaborar com artigos, assim como o reconhecimento ao Diário Oficial por seus serviços técnicos. Ao assinalar que a publicação não trazia ilustrações, procurou vincular esta opção às difíceis condições impostas pela I Guerra e não a um desleixo do editor ou das oficinas de impressão. 
45. Idem, p.IX.

46. Ver a presença de Arthur Neiva junto às instâncias administrativas de São Paulo, especialmente a partir de 1917 , mesmo momento em que Taunay assume a direção do Museu Paulista, em Silva (2006).

47. Ver Taunay (1946, p. 33). É atribuída a Neiva a frase: "São Paulo é uma pujante locomotiva puxando vagões vazios", de acordo com sua biografia publicada pelo Instituto Biológico, do qual foi um dos mais brilhantes organizadores.Ver: $<w w w . i n s t i t u-$ tobiologico.sp.gov.br>, acesso em 31de agosto de 2011.
As difficuldades oriundas da conflagração mundial e a alta excessiva de todo o material de imprensa, sobretudo de gravura, fizeram com que não nos fosse possível illustrar o nosso periódico como desejaríamos faze-lo. Esperamos que em breves e melhores dias haveremos de supprir a semelhante inferioridade e inconveniente voltando aos antigos padrões da Revista. ${ }^{45}$

Ao assumir a direção do Museu Paulista e de sua Revista, em 1917, Taunay precisou "construir" perfil que justificasse sua escolha e atuação. Assim, pelas ambivalências sugeridas pela elaboração da capa em face ao texto de Advertência, no qual pode circunstanciar suas intenções, entende-se que havia resistências ao processo que se conduzia no Museu do estado e que condições extrínsecas a ele - a I Guerra Mundial, principalmente - foram lançadas como justificativa para procedimentos. Se a condição de "cientista" era incontestável na identificação de thering, seria preciso encontrar outra vocação para o diretor que chegava, a sustentar propostas para a instituição.

De toda forma, o processo deveria ser conduzido com muito cuidado, como os registros da "capa" da Revista apontam. Os pressupostos sobre os quais seria construída a autoridade de Taunay não estavam completamente estabelecidos e demandavam esforços e muita perspicácia em sua condução.

No entanto, em 1946, Taunay lembrou estes momentos para enfatizar os apoios que havia recebido na edição da publicação, que herdara da gestão anterior. Ao contribuir para memória do período, suavizou conflitos e procurou se apresentar enquanto autoridade, já naquele momento, delineada e reconhecida. Interessante observar sua ênfase para a contribuição de Arthur Neiva ${ }^{46}$, um dos mais importantes homem de ciência em São Paulo nas primeiras décadas do vinte, com relevantes serviços prestados especialmente em atividades de combate às pragas do café e às epidemias e que, em 1931, cumprira breve mandato na Secretaria do Interior de São Paulo, à qual ainda estava subordinado o Museu Paulista, durante o governo do interventor João Alberto.

A gratidão leva-me a recordar o nome do amigo ilustre e saudosíssimo a quem devi os mais relevantes serviços neste período de adaptação à vida do Instituto à testa do qual fora colocado pelo Governo de São Paulo. Refiro-me a Arthur Neiva, homem de portentosa inteligência e invulgaríssimo conhecimento dos assuntos e dos meios brasileiros. Foi quem me aproximou de vários naturalistas brasileiros dentre os mais eminentes e a quem devi a mais valiosa colaboração para este tomo [tomo X]. Entre eles, Alípio de Miranda Ribeiro, Lauro Travassos, Alberto José de Sampaio, Mello Leitão, Álvaro da Silveira. ${ }^{47}$

No entanto, até a última edição da Revista do Museu Paulista o nome do editor não mais esteve "na capa", enquanto a vinculação com a Universidade de São Paulo permaneceu, desde 1935, encabeçando os tíiulos. Fica, então, aberta a questão: a) tratava-se de reconhecer novos tempos editoriais; b) o peso e tradição da publicação, reconhecidas e expressas por Taunay, iá haviam construído uma identidade de prestígio e competência; c) indica intenção de 
distinguir outro perfil para o editor, inclusive sugerindo certa "vaidade" do antecessor, contribuindo para questioná-lo, em sua atuação.

A referência institucional - o edifício monumento

Ao publicar a Revista do Museu Paulista, Hermann von thering muito possivelmente procurou vincular, por meio de imagem a ser veiculada pela publicação, o Museu recém-organizado e o Monumento do lpiranga, processo ainda em construção. Assim, para a definição de identidade institucional lançou mão de estratégia complexa e multifacetada em que a Revista cumpria o papel de "dar visualidade" aos vínculos que se construía. A capa da Revista apresentouse como espaço privilegiado na associação de imagens e sobreposição de funções. $\bigcirc$ Monumento em sua beleza e grandiosidade conferia ao Museu Paulista posição de destaque na pesquisa científica em desenvolvimento no estado de São Paulo, no Brasil e na América do Sul. A especificidade da construção projetada por Bezzi para (co)memorar o "nascimento da nação" no lpiranga trazia para o Museu nela instalado a condição de representar projeto para São Paulo e o Brasil, no concerto das nações sul-americanas. As características do prédio remetiam ao desenvolvimento técnico-científico europeu, tradição à qual Ihering se filiava, para respaldar movimento de progresso da nação, sustentado em pesquisas de campo e para afirmação da República brasileira, em consolidação.

Portanto, expressar o Museu e as investigações ou projetos que nele se desenvolviam por meio de imagem do monumento e seu entorno revelou-se tão eficaz que até o encerramento da publicação, permaneceu como "marca" da Revista do Museu Paulista.

Evidentemente, Ihering foi meticuloso e cuidadoso no "produzir" esta primeira imagem que seria centralizada na capa da Revista. Cabia também à qualidade de produção referenciar o conteúdo da Revista que ele preparava com tanto cuidado. Assim, o diretor do Museu foi buscar uma técnica de ilustração - a litografia ${ }^{48}$ - capaz não só de dar qualidade de impressão como expressar de forma artística o Monumento que sediava o Museu Paulista.

Da mesma forma, era necessário confiar a preparação da matriz litográfica (Figura 13) à profissional experiente e capaz. Ihering contratou para a produção da matriz, em pedra calcária, W.A. Meyn, ilustrador talentoso e muito bem conceituado que prestava serviços a muitas instituições européias, como a Universidade de Cambridge e o Instituto de Berlim e norte-americanas, como a Universidade de Wisconsin ${ }^{49}$.

Assim, nos oito primeiro volumes da Revista do Museu Paulista, em período que vai de 1896 a 1911 , a capa trouxe sempre uma mesma imagem/ referência, ainda que o prédio-monumento e seu entorno tivessem sofrido algumas
48.A litografia (de lithos, "pedra" e graphein, "escrever") é descoberta no final do século XVIII por Aloys Senefelder (1771-1834). Trata-se de um método de impressão a partir de imagem desenhada sobre base, em geral de calcário especial, conhecida como "pedra litográfica". Após desenho feito com materiais gordurosos (lápis, bastão, pasta etc.), a pedra é tratada com soluções químicas e água que fixam as áreas oleosas do desenho sobre a superfície. A impressão da imagem é obtida por meio de uma prensa litográfica que desliza sobre o papel. Muito utilizada como processo gráfico, foi utilizada intensamente por diferentes artistas.Ainda hoje, o processo é estudado, como forma de ilustração ou produção artística de imagens. Cf.: Enciclopédia Itaú CulturalArtes Visuais; www.itaucultural. org.br, acesso em 31 de agosto de 2011. Ver, sobre o uso da litografia como ilustração gráfica, Paula e Carramillo (1989). O acervo do Museu Paulista guarda uma das pedras litográficas utilizadas para a impressão da imagem do edifício (Figura 13).

49. Os trabalhos de Meyn, especialmente na área de botânica, podem ser vistos em várias obras publicadas entre 1860 e 1920 , indicando profissional respeitado entre os meios científicos da época na produção de ilustrações para o estudo de espécimes, característica das publicações científicas que circulavam especialmente entre especialistas na passagem do século 19 para o 20. São de grande beleza e apuro técnico, evidenciando perfeito domínio da litografia. Possivelmente, o artista trabalhou na Europa, a partir de desenho ou foto a ele enviada por Hermann von Ihering.Talvez, na correspondência em alemão do Fundo Museu Paulista, ainda não totalmente traduzida, seja possível desdobrar estes primeiros passos da pesquisa sobre as relações entre Meyn e o então diretor do Museu. 


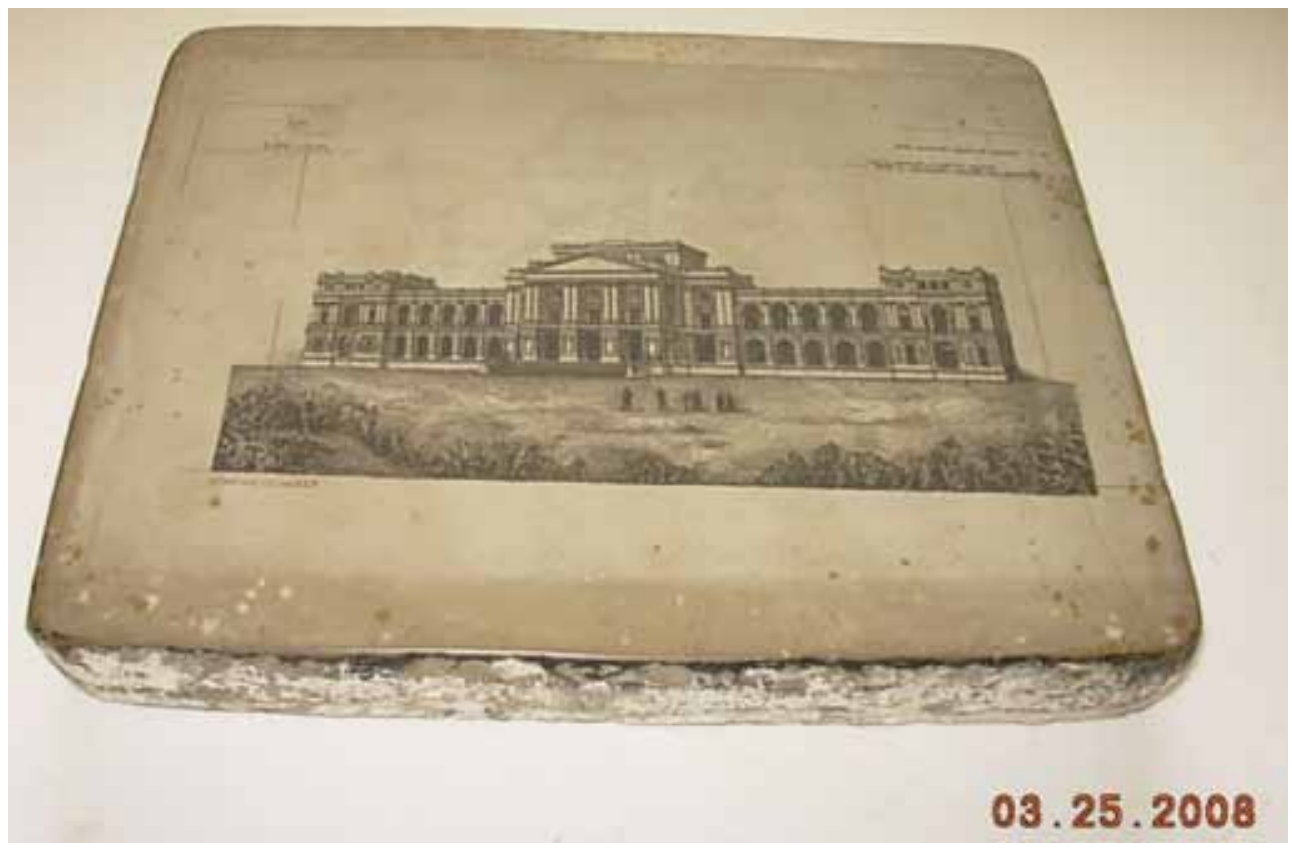

Figura 13 - Matriz litográfica com imagem utilizada na capa dos volumes I a VIII. Acervo do Museu Paulista da USP, São Paulo.

modificações, especialmente quanto ao ajardinamento do espaço frontal à instituição e no arruamento das cercanias, no bairro do lpiranga. De forma instigante, a imagem apresenta como referência uma imagem do Museu, possivelmente foto enviada ao litógrafo na Europa, quando à sua frente se estende um extenso platô. Assim, a "colina do Ipiranga" não se faz presente como referência visual, na veiculação de imagem do Museu Paulista. No entanto, é importante ressaltar que desde a organização do Museu Paulista no Monumento pensava-se em apresentá-lo em perspectiva de avenida a ser construída ligando o centro da cidade ao Ipiranga, para fazer coincidir a referência simbólica do local com sua topografia, ainda que o relevo existente não mais preservasse $\circ$ desnível do solo. Estes projetos vão finalmente se concretizar durante a década de 20 e especialmente 30 do século passado, com o expressivo movimento de terra para a reconfiguração dos jardins defronte ao edifício monumental, a partir das reformas sofridas pelo Museu para o centenário da Independência em 1922. Estas iniciativas foram responsáveis também pela reurbanização do bairro do Ipiranga e reconfiguração de suas principais ruas e avenidas. A permanência da imagem, em contraposição ao contexto de mudanças e transformações vivido em São Paulo, defendeu solidez institucional, estabilidade e continuidade da vida científica do Museu Paulista, onde importantes naturalistas se dedicavam à pesquisa e divulgavam seus trabalhos por meio da Revista.

No entanto, para o volume IX, publicado em 1914, a capa vem com uma "nova imagem" do Museu Paulista, a sugerir o limiar de novos tempos. A 
presença de Hermann von thering é minimizada, enquanto se coloca em destaque a instituição (ver Figura 9). Colocadas lado a lado, as duas imagens sugerem momentos distintos - a partir do volume IX, ainda que isolado do seu entorno, o edifício-monumento apresenta-se por ângulo que destaca sua imponência e solidez, cercado por jardins que the conferem sofisticação. No entanto, desta edição em diante, somente o prédio do Museu Paulista estará presente na capa. O grupo de pessoas, de costas para o edifício-monumento na primeira imagem, e que, estranhamente, parecia observar o artista (Figura 14), será removido; somente o Museu e símbolos como bandeiras farão parte dos referenciais presentes nas imagens de capa (Figura 15 e 16).
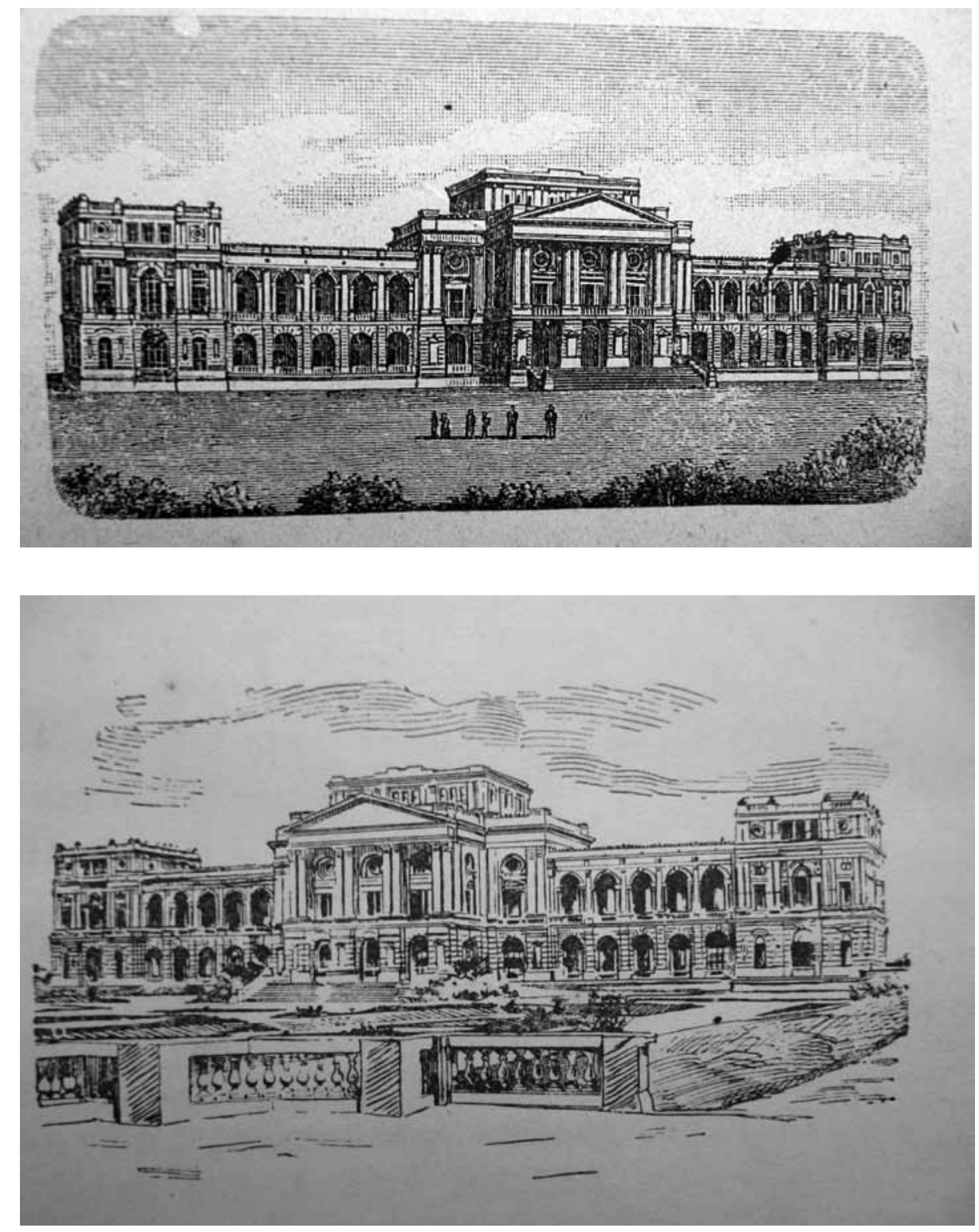

Figura 14 - Litogravura em que se encontram gravadas as seguintes informações: Revista do Museu Paulista 1895 e W.A.Meyn, lith. Inst. Berlin.
Figura 15 - Imagem do edifício-monumento utilizada na capa da Revista, volumes IX (1914), X (1918), XI (1919), XII (1920), XIII (1922), XIV (1926), XV (1927), XVI (1929), XVII 2a. Parte (1932), XVIII (1934). 
Nota-se que a imagem adotada para a identificação da instituição para o último volume da gestão thering (volume IX) foi mantida para os "tomos" $X$ (1918); XI (1919); XII (1920); tomo XIII (1922, momento em que Affonso Taunay edita o primeiro volume de Annaes do Museu Paulista, apresentado como publicação da Seção de História Nacional e Etnografia); tomo XIV (1 926); tomo XV (1 927); tomo XVI (1929); tomo XVII - 2ª. Parte (1932) e tomo XVIII (1934). A importância da capa enquanto sugestão de questões que podiam ser compreendidas pela comunidade de leitores, mas que, necessariamente, não poderiam ser explicitadas, mais uma vez pode ser referenciada: o volume XVII, 19. Parte, publicado em 1931, logo após, portanto, à Revolução de 1930, trouxe foto/imagem que permaneceu "única" (ver Figura 16), para em seguida se retomar, até 1934, imagem anteriormente veiculada.

Na capa de 1935, tomo XIX, quando a vinculação com a Universidade de São Paulo é, pela primeira vez apresentada, retomou-se, como ângulo de reprodução, uma visão frontal do monumento. No entanto, a ênfase, pelo primeiro plano da imagem, fica por conta de palmeira no jardim, enquanto o edifíciomonumento é enquadrado como "linha de horizonte" ou "ponto de fuga", de certa forma distante do observador. (ver Figura 17). Talvez o projeto gráfico da capa também possa ser entendido pelas dificuldades da Imprensa Oficial que, inclusive, motivou a impressão deste volume pelas Escolas Profissionais Salesianas.

O tomo XX, de 1936 (Figura 18), traz imagem tão diferente daquela de 1935 (Figura 17) que se tem a impressão de que o ano decorrido foi

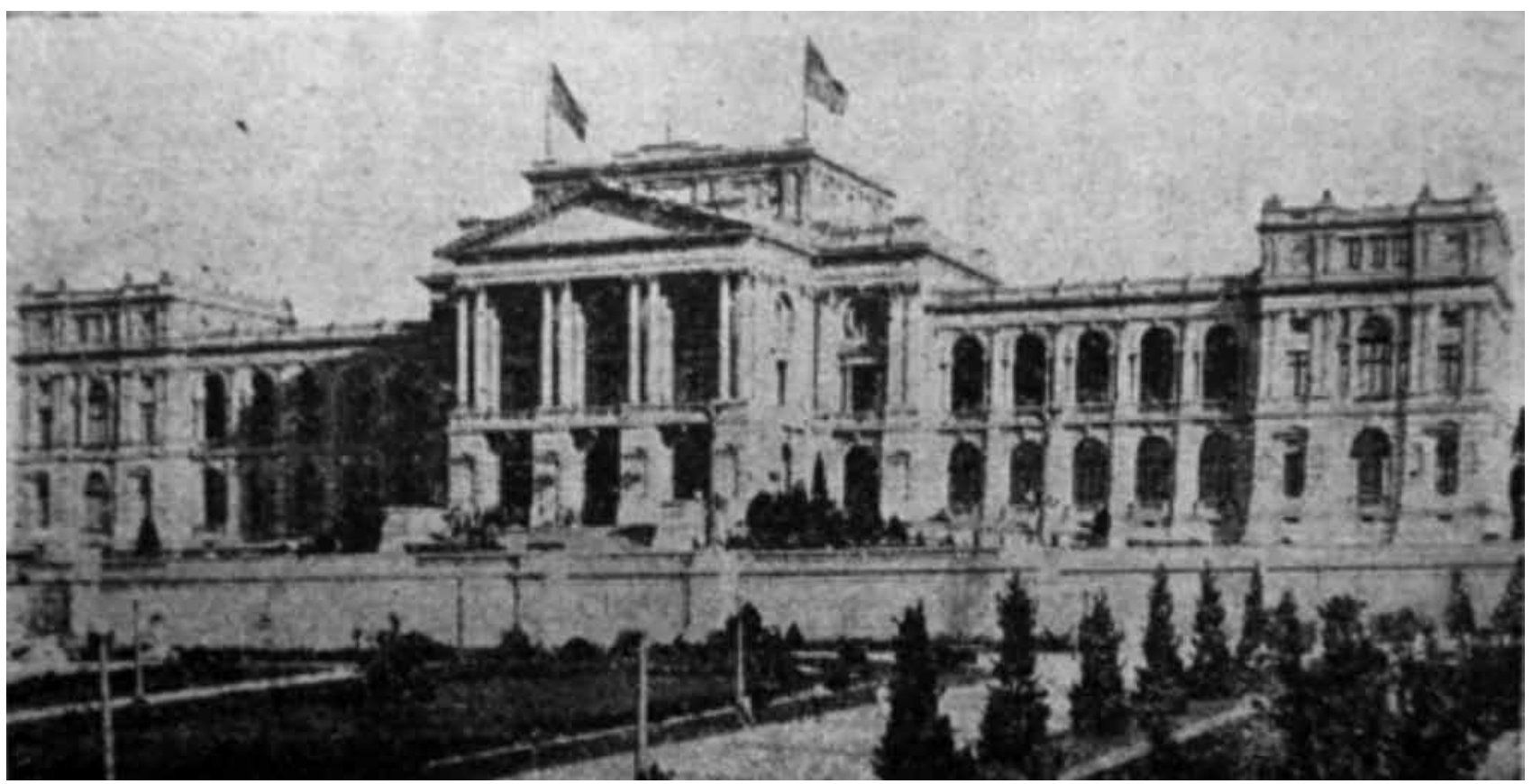

Figura 16 - Imagem do edifício-monumento utilizada na capa da Revista do Museu Paulista, volume XVII, 19. Parte (1931). 


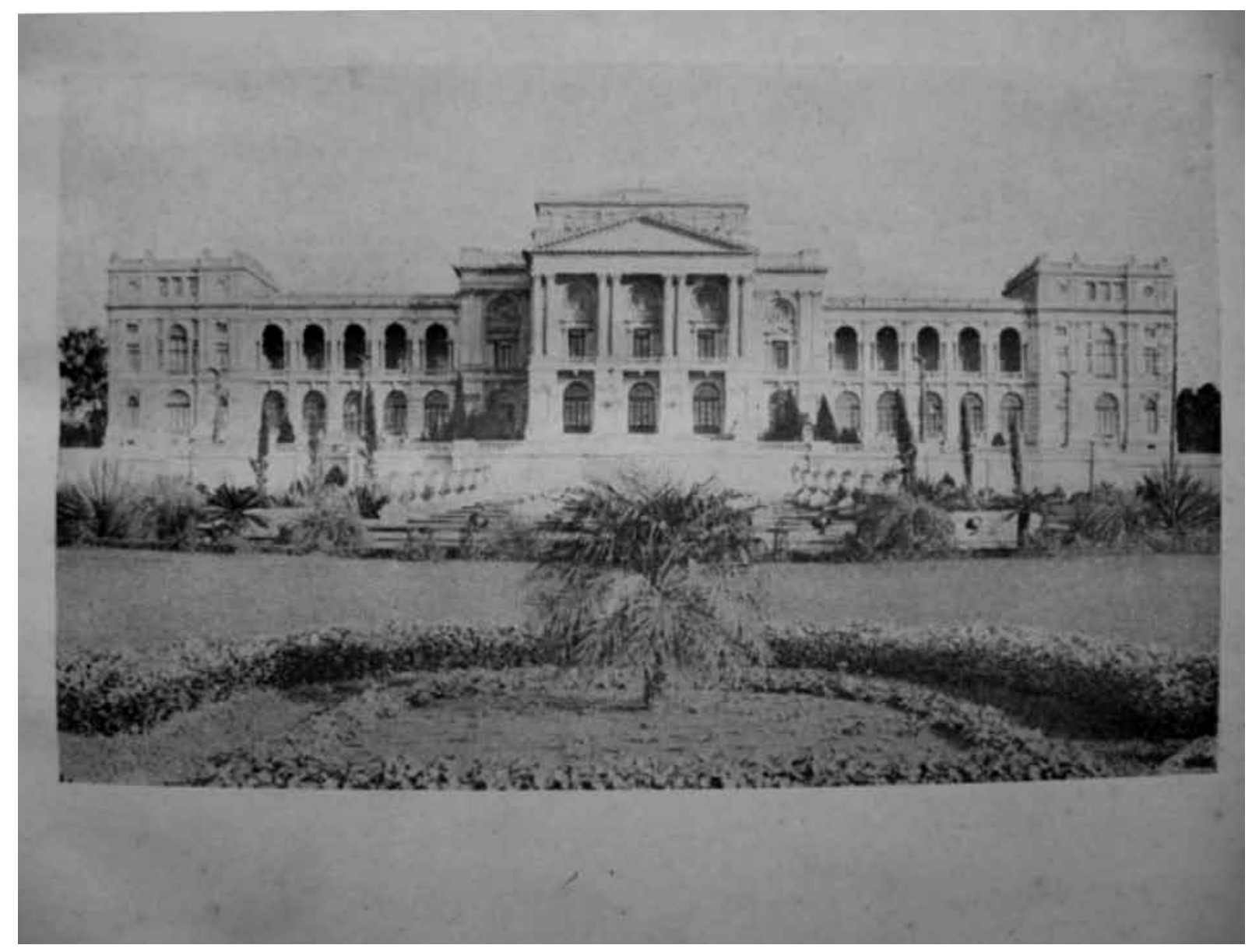

Figura 17 - Imagem do edifício-monumento utilizada na capa da Revista do Museu Paulista, volume XIX (1935).

extremamente denso. $\bigcirc$ edifício-monumento aparece, mais uma vez, em ângulo lateral, embandeirado, com seus jardins frontais, formando conjunto sofisticado. Nada parece agitar a cena, onde o espaço ordenado pelas alamedas e ciprestes, sugere ordem e hierarquia. Apenas no alto do edifício, em seus mastros, as bandeiras parecem tremular. Assim o Museu Paulista foi ainda apresentado por sua Revista, nos tomos XXI, de 1937 e XXIII, de 1938 (Figura 18).

A Revista deixaria de ser publicada, "substituída" por Arquivos de Zoologia do Estado de São Paulo até 1947 - em função do desligamento da seção de zoologia do Museu Paulista -, quando reapareceria como Revista do Museu Paulista, Nova Série. No entanto, este outro momento da publicação, sob direção de Sérgio Buarque de Holanda, dispensou não só "imagens" do Museu como sua vinculação com a Universidade de São Paulo, presente em capa desde o tomo XIX, de 1935. 


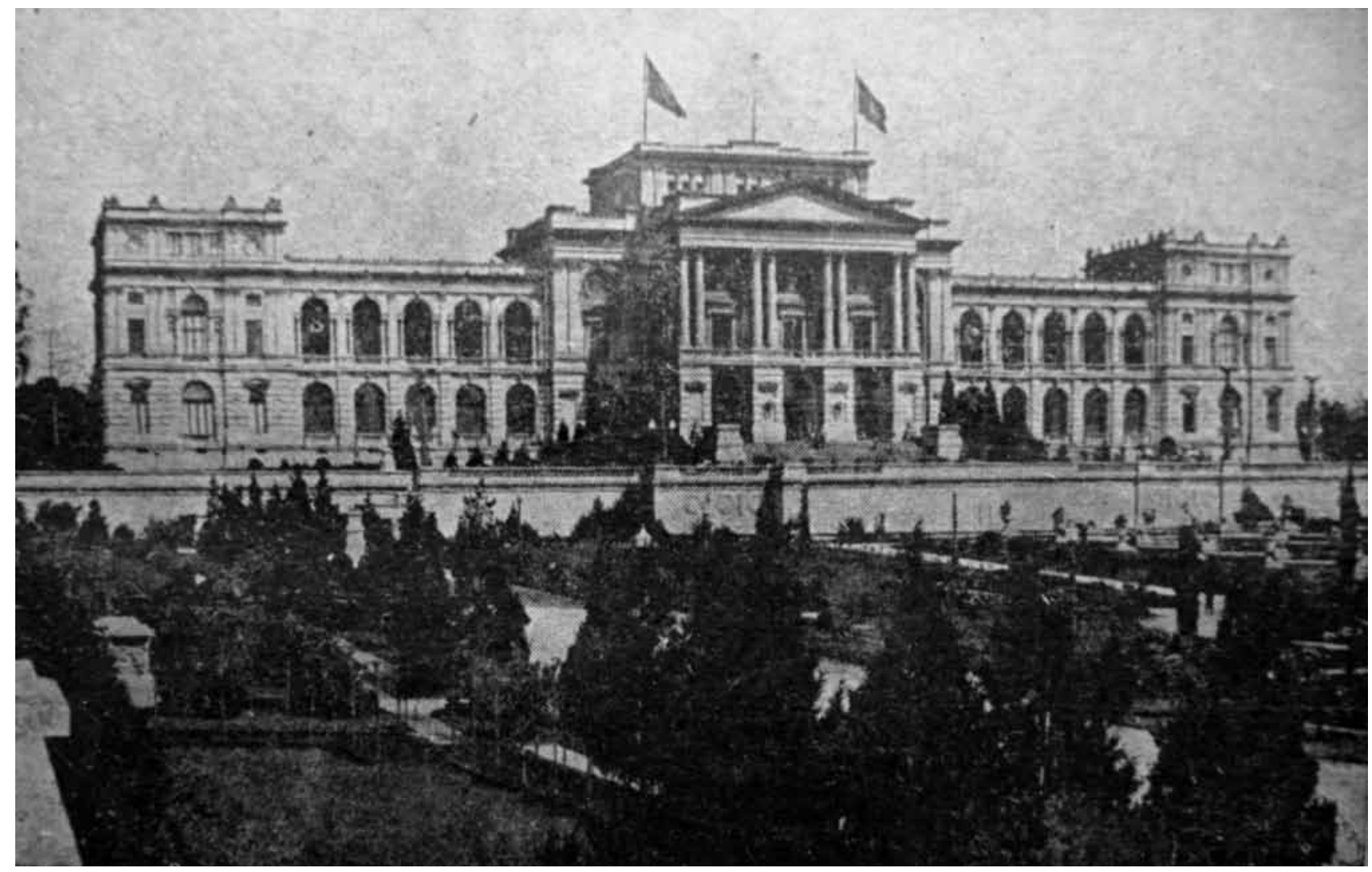

Figura 18 - Imagem do edifício-monumento utilizada na capa da Revista do Museu Paulista, tomos XX (1936), XXI (1937), XXIII (1938).

Considerações finais

Ao avaliar a trajetória da instituição, no momento em que se comemoravam os cinquenta anos de fundação do Museu Paulista, Affonso Taunay cuidou de reconhecer a importância da Revista do Museu Paulista, ao destacar que a publicação havia conseguido "universal crédito entre os maiores centros científicos" com que se relacionava. O tema da Revista ocupou várias páginas do opúsculo de 1946, indicando que ainda naquele momento, quando ela não mais era publicada desde 1938, sua memória merecia deferência e trazia, aos dois primeiros diretores da instituição, peso e expressão nos meios intelectuais em que circularam.

Portanto, trata-se de referenciar função estratégica da Revista, no conjunto de atividades desenvolvidas no Museu Paulista. Neste movimento, tornase fundamental refletir sobre a dimensão "visual" da Revista, ou seja, a capa, em suas estruturas e referências, a expressar propostas e buscar leitores.

Este artigo cuidou de refletir sobre a formulação de uma identidade institucional, que se tornava pública por meio da Revista. A intenção é, mais do 
que "interpretar" signos, buscar as mediações entre o contexto onde foi produzida, os projetos que expressou e os espaços onde circulou e como e quando, por meio das capas, espaço primeiro e marcante na relação com o leitor, pode-se reconhecer vestígios tanto de continuidade como de ruptura nesta trajetória. Assim, é possível sugerir a íntima imbricação alcançada entre o monumento e o Museu, relação construída visualmente por meio das capas e que, até a atualidade, permanece como característica fundamental no reconhecimento da instituição por meio de seu público.

No entanto, interessante movimento de memória/esquecimento também circunda a Revista. Pesquisadores, ao se debruçarem sobre periódicos que circularam em São Paulo nas primeiras décadas do século XX, tendem a construir uma sequência entre a Revista do Museu Paulista, atribuída a lhering e os Anais do Museu Paulista, que passou a circular em 1922 por iniciativa de Taunay. Sugere-se, assim, que o aparecimento da publicação da seção de História - os Anais - tenha substituído os trabalhos da Revista da seção de história natural, o que, de fato, não aconteceu. Mais um indício de embates em torno de espaços de comunicação e construção de sentidos, que se acentuam, na medida em que a formação de opinião pública torna-se mais importante, no contexto político brasileiro. Em que momento e por que, a trajetória da Revista do Museu Paulista é parcialmente apagada? Paradoxalmente, não é possível encontrar, em suas capas, os motivos. Nelas, permaneceram as mesmas estruturas, a sugerir que ainda que Afonso Taunay tenha procurado criar, sob seus cuidados, outra publicação mais estreitamente ligada aos propósitos dos interesses que construía e representava, não teve forças para conferir, visualmente, um papel menor à Revista que herdou de seu antecessor. No entanto, movimento que iniciou e que se fundamentou na especialização do Museu, pôde, inclusive ao recriá-la, propor uma refundação e relegar ao esquecimento sua primeira trajetória.

Retomando, assim, a Revista por suas capas, é possível reconhecer que a escrita da história de período tão denso, deixou "traços", que nos provocam e demandam reflexão. Vestígios a serem recuperados; representações a serem (com) partilhadas, a partir de práticas renovadas de leitura e análise. Nesta dimensão, as capas da Revista do Museu Paulista foram retomadas para serem entendidas enquanto dimensão e expressão de uma escrita da história, configurada pela/na visualidade e que ao se processar, apoiava-se em repertório de grupos e indivíduos que delas se apropriavam e nelas encontravam pertencimento. De modo instigante, o apagamento deste referencial implica num esvaziamento de sentidos e, portanto, em esquecimento. $\bigcirc$ esforço do historiador também remete ao trabalho sensível e delicado de reconfigurar momentos e, assim, buscar as competências, como sugeriu Hartog, para mediar relações entre presente e passado. Assim, é o olhar do historiador que identifica fontes, para recuperar nelas e por meio delas, traços que remetem à configuração de memória, sempre em reconstrução. 


\section{REFERÊNCIAS}

ALVES,Ana Maria de Alencar. O Ipiranga apropriado: ciência, política e poder: o Museu Paulista, 1893-1922. São Paulo: Humanitas/FFLCH-USP, 2001.

AZEVEDO, Maria Von Ihering. Hermann Von Ihering. Boletim do Centro de Estudos Ornitológicos, São Paulo, n. 14, jul. 2000.

BONANÇA, Dora Von Ihering. Rodolpho Von Ihering e sua família. In: PAIVA, Melchíades Pinto (Coord.) A permanência de Rodolpho Von Ibering: livro jubilar pela passagem do primeiro centenário do seu nascimento (1883-19983). Rio de Janeiro: Fundação Brasileira para a Conservação da Natureza, 1984.

BRESCIANI, Maria Stella Martins. Liberalismo: ideologia e controle social: um estudo sobre São Paulo de 1850 a 1910. Tese (Doutorado), Faculdade de Filosofia, Ciências e Letras / Universidade de São Paulo, São Paulo, 1976.

CARDOSO, Rafael (Org.). O design brasileiro antes do design: aspectos da bistória gráfica, 1870-1960. São Paulo: Cosac Naify, 2005.

CARVAlHO, José Murilo de. A formação das almas: o imaginário da República no Brasil. São Paulo: Companhia das Letras, 1990.

CASALECCHI,José Ênio. O Partido Republicano Paulista, 1889-1926. São Paulo: Brasiliense, 1987.

CHARTIER, Roger. $A$ ordem dos livros: leitores, autores e bibliotecas na Europa entre os séculos XIV e XVIII. Brasília: Editora da Universidade de Brasília, 1999.

FIGUERÔA, Silvia F. de Mendonça. As ciências geológicas no Brasil: uma história social e institucional. São Paulo: Hucitec, 1996.

Modernos bandeirantes: a Comissão Geográfica e Geológica de São Paulo e a exploração científica do território paulista (1886-1931). Dissertação (Mestrado), Faculdade de Filosofia, Letras e Ciências Humanas, Universidade de São Paulo, São Paulo, 1987.

FRANÇOZO, Mariana. O Museu Paulista e a história da antropologia no Brasil entre 1946 e 1956. Revista de Antropologia, São Paulo, v. 48, n. 2., jul/dez. 2005.

GOMES,Angela de Castro. História ciência e historiadores na primeira República. In: HEIZER,Alda; VIDEIRA, Antonio Augusto (Org.). Ciência, Civilização e República nos trópicos. Rio de Janeiro: Mauad/Faperj, 2010, p. 11-30.

GUALTIERI, Regina C. L.. Evolucionismo no Brasil: Ciência e Educação nos Museus, 1870/1915. São Paulo: Editora Livraria da Física, 2008.

GUIMARÃES, Manoel Luiz Salgado.Vendo o passado: representação e a escrita da história.Anais do Museu Paulista: História e Cultura Material, São Paulo, v.15, n.2, p.11-30, jul.-dez. 2007.

.História, memória e patrimônio. In: OLIVEIRA,Antonio Barbosa de. (Org.) Universidade e lugares de memória. Rio de Janeiro: UFRJ, 2008, v. 2.

HARTOG, François. Tempos do Mundo, História e Escrita da História. In: GUIMARÃES, Manuel Luiz Salgado Guimarães (Org.). Estudos sobre a escrita da bistória. Rio de Janeiro: 7 Letras, 2006. 
HOLANDA, Sérgio Buarque de. Prefácio. Revista do Museu Paulista, São Paulo, Nova Série, v. I, 1947.

IHERING, Hermann von. História do Monumento do Ypiranga e do Museu Paulista. Revista do Museu Paulista, São Paulo, vol.1, p. 9-31, 1895.

O Museu em 1915. Revista do Museu Paulista, São Paulo, t. X, p. 13-16, 1918.

Prefácio. Revista do Museu Paulista, São Paulo, v. 2, 1897.

JANOTTI, Maria de Lourdes Mônaco. Os subversivos da República. São Paulo: Brasiliense, 1986.

KRESS, Gunther; LEEUWEN, Theo van. Reading Imagens: the grammar of visual design. London: Routlegde, 1996.

LATOUR, Bruno.Jamais fomos modernos: ensaio de antropologia simétrica. Rio de Janeiro: Ed. 34, 1994.

LEITÃO, Candido Mello. A biologia no Brasil. São Paulo: Companhia Editora Nacional, 1937.

LOPES; Maria Margaret; FIGUERÔA, Silvia Fernanda de M..A criação do Museu Paulista na correspondência de Hermann Von Ihering (1850,1930). Anais do Museu Paulista: História e Cultura Material, São Paulo, n. 1, v. 13, p. 315-377, jan.-jun. 2005.

LOVE, Joseph. São Paulo na federação brasileira, 1889-1937. A locomotiva. Rio de Janeiro: Paz e Terra, 1982.

MAKINO, Miyoko.Anais do Museu Paulista: Índice: 1922-1981. Anais do Museu Paulista, São Paulo, t. 30, p. 451-514, 1980/1981.

MAKINO, Miyoko; SILVA, Shirley Ribeiro da; LIMA, Solange Ferraz de; CARVALHO, Vânia Carneiro de. O Serviço de documentação textual e iconografia do Museu Paulista. Anais do Museu Paulista: História e Cultura Material, São Paulo, v. 10-11, n. 1, p. 259-304, 2003.

MARANHÃO, Ricardo (coord.) Um retrato no Jornal - a história de São Paulo na Imprensa Oficial (1891/1994). São Paulo: Imprensa Oficial do Estado, 1994.

MARTINS,Ana Luiza. Revistas em revista: imprensa e práticas culturais em tempo de República, São Paulo (1890-1922). São Paulo: Editora da Universidade de São Paulo; FAPESP; Imprensa Oficial do Estado, 2001.

MENESES, Ulpiano T. Bezerra de.Apresentação da Nova Série. Anais do Museu Paulista: História e Cultura Material, São Paulo, n. 1, p. 5-7, 1993.

Museu Paulista. Estudos Avançados, São Paulo, v. 8, n. 22, p.573-578, set-dez. 1994.

MOACYR, Primitivo. A instrução pública no Estado de São Paulo: a primeira década republicana (1890-1900), v. 2. São Paulo: Cia. Editora Nacional, 1942.

OLIVEIRA, Cecília Helena de Salles. Museu Paulista: espaço de evocação do passado e reflexão sobre a História. Anais do Museu Paulista: História e Cultura Material, São Paulo, v. 10/11, p. 105-126, 2002-2003.

PAULA,Ademar A. De; CARRAMILLO, Mario. Artes gráficas no Brasil: registros 1746-1941. São Paulo: Laserprint, 1989.

Annals of Museu Paulista. v. 20. n.2. July.-Dec. 2012. 
QUEIROZ, Suely Robles Reis de. Os radicais da República. Jacobinismo: ideologia e ação (18931897). São Paulo: Brasiliense, 1986.

REGULAMENTO do Museu Paulista do Estado de São Paulo, Decreto no. 249, de 26 de julho de 1894.

RELATÓRIO de 1894, Cesario Motta. Apud: MOACYR, Primitivo. A instrução pública no Estado de São Paulo: primeira década republicana (1890-1900). $2^{\circ}$. Vol. São Paulo: Companhia Editora Nacional, 1942.

REVISTA do Museu Paulista, São Paulo, v. I (1895) - IX (1914); t. X (1918)- XXIII (1938).

SILVA:André Felipe Candido da.A campanha contra a broca-do-café em São Paulo (1924-19267). História, Ciências, Saúde - Manguinbos, Rio de Janeiro, v. 13, n. 4, p. 957-993, out-dez. 2006.

SIRINELLI, Jean-François. Os intelectuais. In: RÉMOND, René. Por uma bistória política. Rio de Janeiro: Editora UFRJ/FGV, 1996.

SZMRECSÁNYI,Tamás. Origens da liderança científica e tecnológica paulista no século XX. Simpósio Internacional Elites, Cuestión Regional y Estado Nacional:Argentina y America Latina, siglo XIX y primeras décadas del siglo XX, Tucumán (argentina), 24-26 de abril de 1996. Disponível em:<geo25.ige.unicamp.br/site/publicacoes/dpct/Texto-15.doc>, acesso em 31 de maio de 2011.

TAUNAY,Affonso d'E.Advertência. Revista do Museu Paulista, São Paulo, t. X, 1918.

Comemoração do Centenário da solene instituição do Museu Paulista no Palácio do Ipiranga. São Paulo: Imp. Oficial do Estado, 1946. 